\title{
12 Intravasale infecties en sepsis
}

J. Dankert ${ }^{*}$

\subsection{Intravasale infecties}

Infecties in het hart en de bloedbaan worden intravasale infecties genoemd. De circulatie van bloed door het hart is essentieel voor de aanvoer van zuurstof en voedingstoffen naar weefsel en organen en voor de afvoer van de afvalstoffen. In principe bevat het intravasale systeem geen micro-organismen. Bloed is steriel. Als micro-organismen in de bloedbaan komen, worden ze snel verspreid, hetzij vrij in plasma, hetzij gehecht aan of in de bloedcellen (tabel 12.1). Binnen twee minuten bereiken ze dan een capillair systeem, waarin ze kunnen achterblijven. In weefsels en organen kunnen ze soms aan specifieke cellen hechten (tropisme) en na groei specifieke infecties van die weefsels of organen veroorzaken (bijv. hepatitis B-virus in de lever, meningokokken in de meningen). Andere microorganismen veroorzaken infecties door in het bloed of de cellen in het bloed (bijv. Plasmodium-soorten, de oorzaak van malaria) of in bloed- vaten of in het hart te groeien. Deze infecties worden intravasale infecties genoemd.

Op welke wijze komen micro-organismen in de bloedbaan terecht? Dagelijks zijn kortdurend bacteriën aanwezig in het bloed, bijvoorbeeld uit de mondholte na tandenpoetsen of uit het colon na defecatie. De aanwezigheid van bacteriën in het bloed wordt aangeduid met de term bacteriëmie (tabel 12.2). De bacteriëmie na tandenpoetsen of defecatie wordt transiënt genoemd, omdat na enkele minuten de bacteriën door het reticuloendotheliale systeem zijn geklaard en het bloed weer vrij van bacteriën is. Medische onderzoeken en ingrepen waardoor het slijmvlies wordt beschadigd, kunnen ook resulteren in een transiënte bacteriëmie (tabel 12.3). Door beschadiging van slijmvliezen bij geslachtsverkeer kunnen verwekkers van via bloed overdraagbare aandoeningen, bijvoorbeeld hepatitis B-virus en HIV, ook de bloedbaan bereiken. Via een steek van bloedzuigende insecten (muskieten, vlooien, luizen, mijten en teken) kunnen virussen, bacteriën, protozo-

Tabel 12.1 Bij infecties aantoonbare micro-organismen en hun lokalisatie.

\begin{tabular}{|c|c|c|c|c|}
\hline micro-organismen & plasma & $\begin{array}{l}\text { leuko-, mono-, } \\
\text { lymfocyten }\end{array}$ & granulocyten & erytrocyten \\
\hline virussen & $\begin{array}{l}\text { poliovirus } \\
\text { gelekoortsvirus } \\
\text { hepatitis B-virus }\end{array}$ & $\begin{array}{l}\text { mazelenvirus } \\
\text { Epstein-Barr-virus } \\
\text { cytomegalovirus } \\
\text { HIV-virus } \\
\text { hepatitis C }\end{array}$ & & \\
\hline bacteriën & $\begin{array}{l}\text { Gram-positieve kokken } \\
\text { Gram-negatieve staven } \\
\text { Gram-negatieve kokken } \\
\text { Leptospira, Borrelia }\end{array}$ & $\begin{array}{l}\text { Brucella } \\
\text { Listeria } \\
\text { Neisseria meningitidis } \\
\text { Mycobacterium }\end{array}$ & diverse soorten & Bartonella \\
\hline protozoën & Trypanosoma & $\begin{array}{l}\text { Leishmania, } \\
\text { Toxoplasma gondii }\end{array}$ & $\begin{array}{l}\text { Babesia } \\
\text { Plasmodium }\end{array}$ & \\
\hline
\end{tabular}

\footnotetext{
* Prof.dr. J. Dankert is overleden in 2004.
} 
Tabel 12.2 Definitie van begrippen bij intravasale infecties en sepsis.

bacteriëmie
fungemie/candidemie
viremie
parasitemie
infectie
systemisch inflammatoire-
responssyndroom (SIRS)
responssyndroom (SIRS)

sepsis

ernstige sepsis

septische shock

multipel orgaanfalen (MOF) aanwezigheid van bacteriën in de bloedbaan

aanwezigheid van schimmels of gisten in de bloedbaan

aanwezigheid van virussen in de bloedbaan

aanwezigheid van parasieten in de bloedbaan

aanwezigheid of invasie van micro-organismen in weefsels of organen gepaard gaand met een lokale of gegeneraliseerde schade aan de gastheer

een gegeneraliseerde ontstekingsreactie door diverse oorzaken, onder meer door een infectie

kenmerken:

- lichaamstemperatuur $>38^{\circ} \mathrm{C}$ of $<36^{\circ} \mathrm{C}$

- hartfrequentie $>90 / \mathrm{min}$.

- ademhalingsfrequentie $>20 / \mathrm{min}$.

- leukocyten (in bloed) $>12.000 / \mathrm{ml}$ of $<4000 / \mathrm{ml}$

criterium: twee of meer kenmerken aanwezig

een SIRS ten gevolge van een infectie

een sepsis gepaard gaand met orgaanfalen blijkend uit bijvoorbeeld een lage bloeddruk, hypoxie, oligurie of een verandering van gedrag of daling van bewustzijn

ernstige sepsis met blijvend lage bloeddruk, ondanks hart- en vaatondersteunende maatregelen

verlies van functies van diverse organen waarbij zonder medisch ingrijpen geen herstel mogelijk is en en sommige parasieten de bloedbaan bereiken. Een derde oorzaak van de aanwezigheid van micro-organismen in de bloedbaan is een bestaande infectie in weefsels of organen. Vanuit de infectiehaard bereiken micro-organismen via lymfogene afvoer de bloedbaan en kan, indien het een bacteriële infectie betreft, secundair een bacteriëmie ontstaan.

Urineweg- en luchtweginfecties zijn dikwijls de porte d'entrée voor een bacteriëmie.

Intravasale infecties worden onderscheiden in primaire en secundaire infecties. Primaire intravasale infecties ontstaan in de bloedbaan. Men spreekt van een secundaire infectie van de bloedbaan als de primaire infectiehaard buiten de bloedbaan is gelegen. Primaire intravasale infecties kunnen het gevolg zijn van een beschadiging van het capillaire bed in weefsel of van het endotheel van hart of bloedvaten. Micro-organismen, meestal bacteriën of gisten, en veelal transiënt aanwezig in de circulatie, kunnen ter plaatse van de beschadigingen hechten en uitgroeien. Bijvoorbeeld bij jonge kinderen kan door een trap tegen de enkel bij het voetballen het capillaire bed van de metafyse van een groeiend scheenbeen worden beschadigd. Een transiënte bacteriëmie door Staphylococcus aureus kan aanleiding geven tot een ernstige infectie van het bot (osteomyelitis). Als het endotheel van hart en bloedvaten beschadigd is, kunnen daar circulerende micro-organismen op de binnenzijde van het hart of van een bloedvat hechten en gaan groeien, met als gevolg een intravasale infectie. Endocarditis is een primaire intravasale infectie die zich bevindt op of in het endotheel van het hart, het endocardium. Endarteriitis is een infectie die zich ontwikkelt op het endotheel van een arterie. Een infectie van een vene wordt aangeduid als purulente (thrombo)phlebitis. Ook geïmplanteerde biomaterialen - bijvoorbeeld een hartkunstklep 
Tabel 12.3 Oorzaken van transiënte bacteriëmie.

\begin{tabular}{|c|c|c|}
\hline porte d'entrée & beschadiging van slijmvlies door & $\begin{array}{l}\text { kans op transiënte } \\
\text { bacteriëmie }^{1}\end{array}$ \\
\hline \multirow[t]{4}{*}{ mondholte } & bijten op harde zuurtjes & ++ \\
\hline & tandenpoetsen & ++ \\
\hline & tandextractie & ++ \\
\hline & kaakchirurgische ingrepen & +++ \\
\hline \multirow[t]{2}{*}{ bovenste luchtwegen } & tonsillectomie & ++ \\
\hline & nasotracheale intubatie & + \\
\hline \multirow[t]{4}{*}{ maag-darmkanaal } & endoscopie van maag/dunne darm & + \\
\hline & colonoscopie & + \\
\hline & bariumklysma & + \\
\hline & leverbiopsie & + \\
\hline \multirow[t]{4}{*}{ urinewegen } & urinewegkatheter inbrengen & + \\
\hline & urinewegkatheter verwijderen & ++ \\
\hline & cystoscopie & + \\
\hline & transurethrale prostatectomie & ++ \\
\hline geboortekanaal & vaginale geboorte & + \\
\hline
\end{tabular}

$1+<20 \% ;++\sim 50 \% ;+++>50 \%$.

of een in de bloedbaan aangebrachte kunststof katheter, waarop zich gemakkelijk micro-organismen hechten - zijn vaak de oorzaak van primaire intravasale infecties.

Indien klinische verschijnselen ontstaan door in de bloedbaan circulerende micro-organismen, is er sprake van sepsis.

\subsection{Sepsis, oud en nieuw}

'Deze patiënt heeft een positieve bloedkweek.' 'Mijnheer E. heeft een sepsis.' 'Mevrouw B. wordt septisch.' 'Patiënt D. in het hoekbed lijkt een ernstige sepsis te krijgen.' Dagelijks zijn deze termen op verpleegafdelingen te horen. Ook buiten het ziekenhuis kunnen patiënten septisch worden of een sepsis krijgen. Wat is de betekenis van deze termen?

Tot voor kort werden septische verschijnselen toegeschreven aan de aanwezigheid van microorganismen, van microbiële bestanddelen of van toxische producten in de bloedbaan: een bloedvergiftiging. De geïnfecteerde patiënt werd sep- tisch genoemd als hij klaagde over koude rillingen en koorts, en als de lichaamstemperatuur te laag (hypothermie) en de ademhaling (tachypneu) en de hartslag (tachycardie) te snel waren. De diagnose sepsis werd ook gebruikt als uit het klinisch microbiologisch laboratorium de melding kwam dat de bloedkweken van een patiënt positief waren. Bloedkweken van 'septische' patiënten zijn echter dikwijls negatief. Dit komt doordat 30-50\% van de patiënten met septische verschijnselen een (gelokaliseerde) bacteriële infectie heeft waarbij bacteriën niet in de bloedbaan circuleren. Bloedkweken van patiënten die septisch zijn door een infectie ten gevolge van virussen, protozoën of parasieten, zijn ook vrijwel altijd negatief, en patiënten met een infectie door gisten of schimmels meestal. Bovendien komen septische verschijnselen ook voor bij niet-geïnfecteerde patiënten (fig. 12.1). Vanzelfsprekend zijn de bloedkweken van deze laatste groep patiënten ook negatief.

Tegenwoordig worden bovengenoemde ziekteverschijnselen aangeduid als klinische manifestaties van een gegeneraliseerd ontstekingspro- 


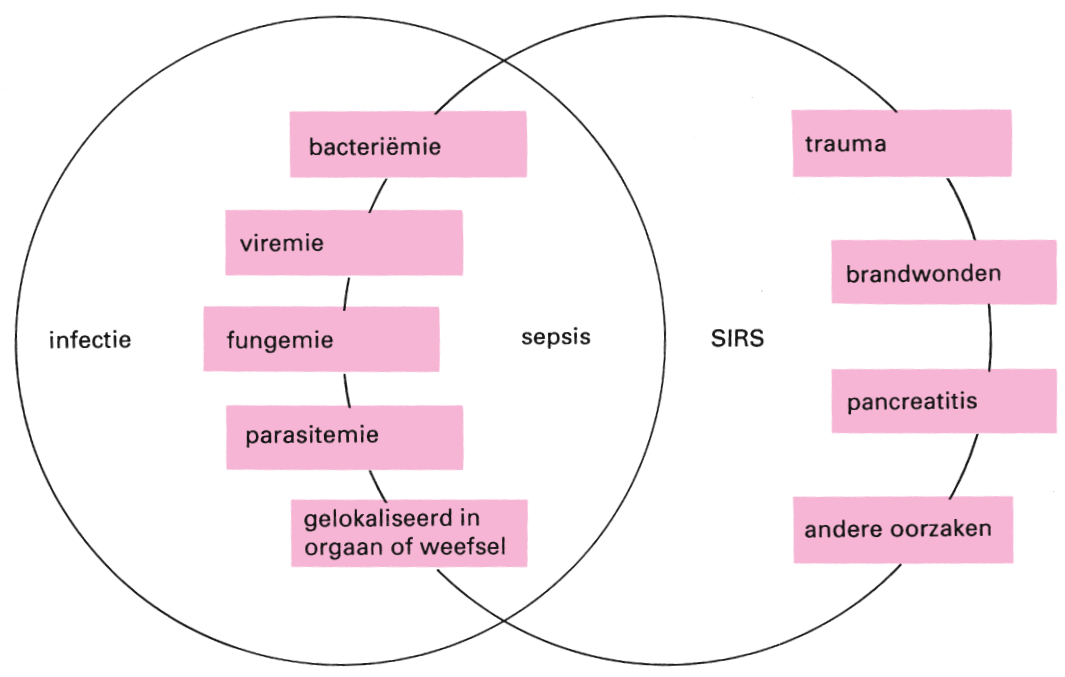

Figuur 12.1 De relatie tussen oorzaken van het systemische inflammatoire-responssyndroom (SIRS) en sepsis.

ces, gedefinieerd als SIRS, de afkorting van het systemische inflammatoire-responssyndroom (tabel 12.2). SIRS kan velerlei oorzaken hebben (fig. 12.1), onder andere systemische of gelokaliseerde infecties. Indien SIRS het gevolg is van een infectie spreekt men, afhankelijk van de ernst van het klinisch beeld, van sepsis, ernstige sepsis of septische shock (zie tabel 12.2). SIRS kan bij infecties echter ontbreken, zelfs bij aanwezigheid van bacteriën in de bloedbaan. Ook virussen (viremie), gisten en schimmels (fungemie) en parasieten (parasitemie) kunnen in de bloedbaan circuleren zonder dat er tekenen van SIRS ontstaan (fig. 12.1). Daar tegenover staat dat patiënten die met antimicrobiële middelen worden behandeld, waardoor het micro-organisme dat de infectie veroorzaakte gedood is, nog wel tekenen van SIRS kunnen vertonen door de aanwezigheid van bacteriële bestanddelen. Verschijnselen van SIRS kunnen zelfs ontstaan zonder dat er sprake is van een infectie, bijvoorbeeld ten gevolge van weefselschade door een ongeval, verbranding of door de inwerking van uit de pancreas (alvleesklier) vrijgekomen enzymen in het kader van een pancreatitis (een chemisch geïnduceerde ontsteking). Waardoor ontstaan de verschijnselen van SIRS? SIRS is het gevolg van de activatie van endotheelcellen van de bloedvaten, de reticulo-endotheliale cellen in milt en lever en alveolaire macrofagen in de longen. De activatie die leidt tot productie van ontstekingsmediatoren en stollings- factoren, kan teweeggebracht worden door in de bloedbaan circulerende micro-organismen, maar ook door microbiële bestanddelen (celwandcomponenten, toxinen) en pro-inflammatoire ontstekingsmediatoren (zie ook hfdst. 1) die vanuit geinfecteerde of getraumatiseerde weefsels in de bloedbaan terecht kunnen komen.

Elke infectie en trauma van weefsels gaat gepaard met een ontstekingsreactie en wordt aangeduid met het vervoegsel -itis. Het is niet alleen de aanwezigheid van levende micro-organismen in weefsels of organen waardoor een ontstekingsreactie kan ontstaan. Ook rondom bestanddelen van micro-organismen, dode micro-organismen, microbiële toxinen en andere corpora aliena ontstaat een microkosmos waarin mediatoren (cytokinen) een ontstekingsreactie induceren. Er kan dus sprake zijn van een steriele ontsteking. Voor een bespreking van het mechanisme van de ontstekingsreactie wordt verwezen naar hoofdstuk 1.

Heeft een patiënt een SIRS-reactie waarbij hemodynamische afwijkingen en stoornissen van diverse organen ontstaan, dan is er sprake van ernstige sepsis en kan een septische shock optreden (tabel 12.2). Bij ernstige sepsis is vrijwel elk orgaansysteem en elke orgaanfunctie gestoord.

- Bloedsomloop. Door de ontstekingsreactie wordt het endotheel van de bloedvaten beschadigd, waardoor de permeabiliteit van het capillairbed toeneemt en er vocht uit de bloed- 
baan lekt. Dan ontstaat een interstitieel oedeem. De huid voelt warm aan. Op de beschadigde endotheelcellen hechten zich bloedplaatjes (trombocyten), en wordt het stollingssysteem geactiveerd, waardoor de weefselperfusie wordt gehinderd en weefsels minder zuurstof krijgen aangevoerd (hypoxie). Door het verbruik van trombocyten en stollingsfactoren kunnen op den duur bloedingen in de huid (petechiae) en in organen ontstaan, zoals in de hersenen en in het maagdarmkanaal, die levensbedreigend zijn.

- Hart. De functie van de hartspier wordt nadelig beïnvloed door de in de circulatie vrijkomende stoffen en door de vasodilatatie in het perifere vaatbed (d.w.z. lage perifere weerstand), waardoor de bloeddruk daalt (hypotensie) (fig. 12.2). Bij patiënten met langer bestaande ernstige sepsis neemt de hartactie af en daalt het hartminuutvolume. Dan neemt de perifere weerstand door reflectoire vasoconstrictie toe. De huid van handen en voeten voelt dan koud aan en krijgt een paarsblauwe kleur. Dat zijn tekenen van de septische shock (fig. 12.2). De systolische bloeddruk is dan veel lager dan de normale systolische bloeddruk van de patiënt.

- Longen. De verhoogde capillaire permeabiliteit in de longen leidt ertoe dat vocht zich ophoopt in het interstitium en in de alveoli (longoedeem). Hierdoor worden de opname van zuurstof en de afgifte van koolzuurgas belemmerd. De respiratoire insufficiëntie maakt beademing van de septische patiënt noodzakelijk en wordt ARDS ('adult respiratory distress syndrome') genoemd.

- Lever. De reticulo-endotheliale cellen (Kupffer-cellen) worden geactiveerd en de hepati- sche gluconeogenese is verhoogd. Na ongeveer een week treden stoornissen in de bilirubinesynthese op, waardoor patiënten icterisch kunnen worden.

- Maag-darmkanaal. Door de verminderde bloedvoorziening en hypoxie neemt de peristaltiek van maag en colon af en kan necrose van het darmslijmvlies ontstaan met darmbloedingen als gevolg.

- Nieren. Al snel ontstaat necrose van de niertubuli met als gevolg een acute nierinsufficiëntie die gepaard gaat met een sterk verminderde urineproductie (oligurie).

- Hersenen. Patiënten zijn door de hypoxie vaak onrustig en verward en kunnen zelfs in coma raken.

- Metabolisme. Kenmerkend voor (ernstige) sepsis is het hypermetabolisme met een verhoogde hepatische gluconeogenese en ureogenese en een verhoogde uitscheiding van ureum in urine. De patiënt raakt in een katabole fase. Hierbij treden proteolyse van spierweefsel en lipolyse van vetweefsel op, waarmee getracht wordt de behoefte aan glucose op te vangen. De hypoxie induceert een gestoorde Krebs-cyclus in de weefselcellen, waardoor glycolyse ontstaat. Het gevormde pyrodruivenzuur wordt gereduceerd tot melkzuur, resulterend in lactaat- of metabole acidose.

Bij ernstige sepsis treedt een sneeuwbaleffect op als het ene na het andere orgaan of orgaansysteem in het ongerede raakt. Deze fase wordt toepasselijk aangeduid als het syndroom van het multipel orgaanfalen (MOF) en leidt zonder medisch ingrijpen onherroepelijk tot de dood (fig. 12.2).

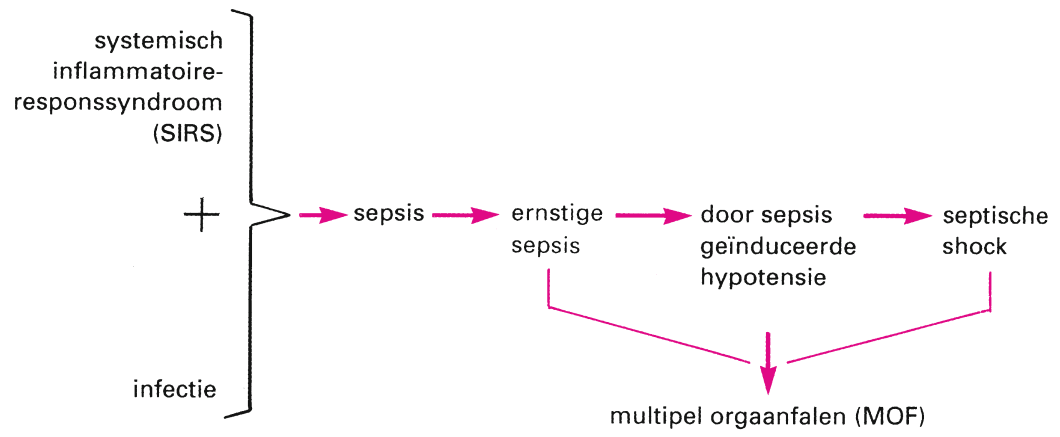

Figuur 12.2 De gevolgen van SIRS en infectie. 


\subsection{Endocarditis}

\subsubsection{Inleiding}

Endocarditis is een infectie op en van het endotheel van het hart, het endocard. In vrijwel alle gevallen wordt deze infectie door bacteriën veroorzaakt; daarom wordt ook wel gesproken van bacteriële endocarditis. Gisten en schimmels kunnen echter ook endocarditis veroorzaken. Endocarditis kan in de rechter- of linkerharthelft ontstaan, meestal op één van de kleppen, maar de infectie kan ook gelokaliseerd zijn op de chordae tendineae of op het endocard van een ventrikel of atrium.

Er zijn verschillende vormen van endocarditis, gerekend naar de plaats in het hart, het beloop van de ziekte voor de behandeling, de microbiële etiologie, en de aanwezigheid van kunstkleppen of ander prothetisch materiaal in het hart. Endocarditis die is ontstaan op een beschadigd of onbeschadigd endocard, wordt natieve endocarditis genoemd. De beschadiging van het endocard is het gevolg van aangeboren of verworven hartafwijkingen. Natieve endocarditis is meestal een infectie van de linkerharthelft, waarbij de infectie even vaak voorkomt op de mitraliskleppen als op de aortakleppen. Rechtszijdige natieve endocarditis komt vooral voor bij patiënten met een aangeboren ventrikelseptumdefect en bij i.v.-drugsgebruikers. Bij laatstgenoemden is de endocarditis meestal gelokaliseerd op de tricuspidaliskleppen. Endocarditis bij patiënten na een hartoperatie bij wie een hartkunstklep of ander prothetisch materiaal is geimplanteerd, wordt aangeduid met de term prothetische endocarditis. Ontstaat de endocarditis in het eerste jaar na de operatie, dan is er sprake van een vroege prothetische endocarditis. Late prothetische endocarditis ontstaat meer dan een jaar na de operatie.

Het klinisch beloop van endocarditis kan worden gekenmerkt door een subfebriele temperatuur, een malaisegevoel en een geleidelijk ontstaan van de diverse afwijkingen die passen bij endocarditis. Dan is sprake van subacute endocarditis, ook wel endocarditis lenta genoemd. Bij een acute endocarditis staan septische verschijnselen, die in enkele dagen zijn ontstaan, op de voorgrond. Beide klinische vormen van endocarditis kunnen zich voordoen bij patiënten met of zonder preëxistente hartafwijkingen en bij patiënten met hartkunstkleppen. Subacute endocarditis wordt veroorzaakt door veelal minder virulente bacteriën, terwijl acute endocarditis ontstaat door virulente, invasieve bacteriën.

De verschillende vormen van endocarditis komen niet in dezelfde mate voor: $80-85 \%$ van de patiënten met endocarditis heeft een natieve endocarditis, waarvan bij ongeveer tweederde een subacuut verloop wordt gezien. Het type endocarditis en de microbiële oorzaak beïnvloeden het beloop en de keuze van de behandeling en de prognose van de patiënt. Daarom wordt tegenwoordig de endocarditis naar deze kenmerken bijvoorbeeld als volgt omschreven: patiënt heeft een linkszijdige, natieve, subacute endocarditis van de mitraliskleppen door viridans-streptokokken, of patiënt heeft een vroege prothetische endocarditis van de aortakunstklep door Staphylococcus epidermidis.

\subsubsection{Subacute endocarditis}

\section{casus 1}

De 32-jarige leraar GB werd opgenomen wegens malaisegevoel, koorts, hoofdpijn, kortademigheid en een stekend gevoel voor op de borst. Zes weken eerder waren het malaisegevoel en de koorts tijdens een vakantieweek in de Harz, Duitsland, begonnen. Kort na thuiskomst was patiënt naar de huisarts gegaan, die hem vanwege de koorts en kortademigheid voor een luchtweginfectie tien dagen amoxicilline voorschreef. De klachten verbeterden daarop, maar ongeveer een week na de antibiotische behandeling kwamen de klachten terug. In de drie weken voor opname kwam ook de koorts, 38$38,5^{\circ} \mathrm{C}$, weer terug, nam de eetlust af en viel hij $6 \mathrm{~kg}$ af. In de laatste week voor opname kreeg hij een doffe hoofdpijn in het voorhoofd en opnieuw een stekend gevoel voor op de borst. De 
huisarts besloot de patiënt te laten opnemen. Bij opname werd een bleke, slanke man gezien. Zijn lichaamstemperatuur was $38,3^{\circ} \mathrm{C}$, de hartfrequentie was 90/min., de bloeddruk $130 / 60 \mathrm{mmHg}$. Bij onderzoek werden in het slijmvlies van de mond drie bloedinkjes (petechiën) gezien. Er waren geen afwijkingen aan het gebit zichtbaar. In de conjunctiva en in de huid van handen, vingers, ellebogen en voeten waren geen afwijkingen. Bij oogspiegelen waren de oogfundi normaal. Bij auscultatie van het hart werd een systolische souffle graad III/VI gehoord, verdacht voor een aortastenose en een korte hoogblazende vroege diastolische souffle, graad II/VI, links onder naast het sternum, wijzend op een aorta-insufficiëntie. De milt was niet palpabel. De laboratoriumgegevens van het bloed waren normaal, behalve een verhoogde bezinking ( $86 \mathrm{~mm}$ in het eerste uur) en een licht verhoogd serumcreatininegehalte en een laag hemoglobinegehalte. Bij onderzoek van het urinesediment werd een microscopische hematurie gevonden.

Tweedimensionale transthoracale echocardiografie toonde een aorta met een bicuspidale klep, waarvan één lang was en één verdikt, met vegetaties. De drie bloedkweken afgenomen op de dag van opname waren alle een dag later positief en verdacht voor streptokokken in een Gram-preparaat. Een dag later groeiden op de beënte bloedplaten vergroenende kolonies, verdacht voor viridans-streptokokken, die werden geïdentificeerd als Streptococcus sanguis. De diagnose luidt: subacute natieve linkszijdige endocarditis van de aortakleppen door S.sanguis. Het isolaat was goed gevoelig voor penicilline. De na afname van de bloedkweken reeds begonnen behandeling bestond uit intraveneuze toediening van hoge doses penicilline $G$ in combinatie met gentamicine. Deze behandeling werd twee weken gecontinueerd, daarna volgde nog twee weken behandeling met penicilline alleen. Het klinisch beloop was ongestoord en de patiënt heeft zijn werk twee maanden daarna hervat.

\section{Pathogenese}

Hoe heeft S.sanguis het hart van patiënt GB bereikt en een endocarditis kunnen veroorzaken? In alle gevallen van negatieve endocarditis zijn bacteriën via het bloed (een bacteriëmie) in het hart terechtgekomen. Bacteriën komen in het bloed als slijmvliezen waarop een residente (endogene) microflora voorkomt, worden getraumatiseerd, ernstig of licht. Ook vanuit lokale infecties kunnen bacteriën in de bloedbaan komen. Echter, GB had geen infecties gehad die de porte d'entrée zouden kunnen zijn geweest voor de bacteriëmie. Slijmvliesbeschadigingen doen zich voor bij activiteiten van alledag en bij diagnostische ingrepen, instrumentaties, tandheelkundige ingrepen en operaties (tabel 12.3). Uit onderzoek is gebleken dat negen van de tien patiënten met natieve subacute endocarditis geen van de in tabel 12.3 genoemde tandheelkundige en medische ingrepen hadden ondergaan.

Als bacteriëmie echter zo vaak voorkomt, waarom is dan de frequentie van subacute natieve endocarditis niet hoger? Een van de redenen is dat weinig virulente bacteriën als S.sanguis zich op een normaal endocardium niet kunnen hechten. Voor het ontstaan van subacute natieve endocarditis is naast een transiënte bacteriëmie ook een beschadigd endocard nodig (fig. 12.3). Zelfs minuscule endocardafwijkingen predisponeren al voor een infectie. Het is dan ook niet verwonderlijk dat bij meer dan de helft van de patiënten met endocarditis vooraf geen hartafwijkingen bekend zijn. Onderzoek van overleden patiënten zonder endocarditis heeft uitgewezen dat endocardbeschadigingen niet zeldzaam zijn. Het endocard wordt met name beschadigd bij hartafwijkingen waarbij het bloed met een groot drukverval door een nauwe opening terugstroomt naar atrium of ventrikel. Hartafwijkingen waarbij dit Venturi-effect optreedt, zijn mitralisklepinsufficiëntie, mitralisklepprolaps in combinatie met een insufficiëntie, aortaklepinsufficiëntie, tricuspidalisklepinsufficiëntie en ventrikelseptumdefect. Op het beschadigde endocard ontstaat door activatie van bloedplaatjes een microstolsel (fig. 12.3), dat opgebouwd is uit een fibrinenetwerk waarin bloedplaatjes zijn gevangen. Dit stolsel wordt aangeduid met de term niet-bacteriële trombotische endocarditis. In het Neder- 


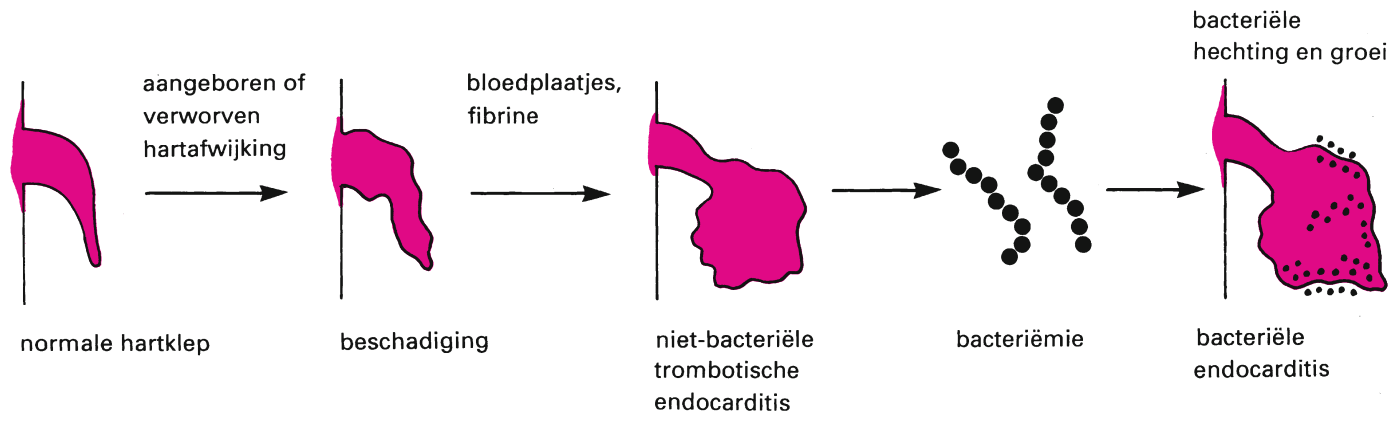

Figuur 12.3 Pathogenese van natieve endocarditis.

lands wordt dit stolsel kortweg vegetatie genoemd. In geval van een bacteriëmie kunnen zich bacteriën op dergelijke vegetaties hechten (fig. 12.3). Een kenmerk van de bacteriesoorten die endocarditis veroorzaken, is dat ze ongevoelig zijn voor aspecifieke afweermechanismen in het bloed zoals complementfactoren en bactericide eiwitten (trombocidinen) uit bloedplaatjes, én dat ze zich kunnen hechten aan vegetaties.

Een subacute endocarditis wordt meestal door weinig virulente bacteriesoorten veroorzaakt. Voordat de eerste verschijnselen van subacute endocarditis ontstaan, hebben de bacteriën zich al een tot twee weken eerder op de vegetatie gehecht. Door de bacteriën op de vegetatie ontstaat opnieuw aggregatie van bloedplaatjes en wordt een nieuw netwerk van fibrine gevormd, dat de

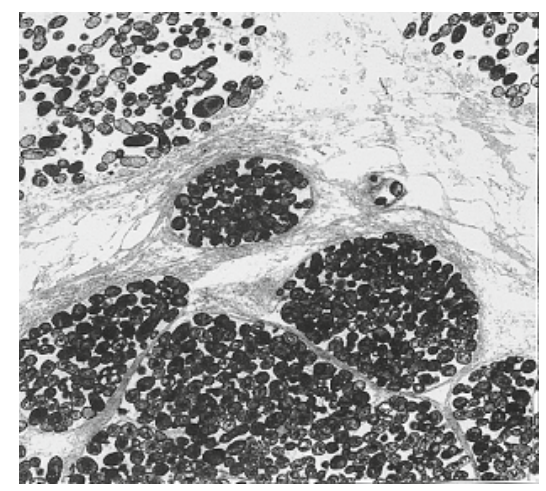

Figuur 12.4 Doorsnede van een vegetatie van een patiënt met endocarditis: de bacteriën liggen samengepakt in de vegetatie. (Bron: D. Durack en P.B. Beeson. In: S.H. Rahimtoola, ed. Infective endocarditis. New York: Grune \& Stratton, 1978.) op de vegetatie aanwezige delende bacteriën afdekt (fig. 12.4). Uit de geïnfecteerde vegetatie komen bacteriën die loslaten uit het fibrinebloedplaatjesnetwerk, in de bloedbaan terecht. Zo ontstaat een min of meer continue bacteriëmie en hechten zich steeds opnieuw bacteriën vanuit de bloedbaan aan de vegetatie, waardoor de vegetatie steeds groter wordt en het aantal bacteriën erin toeneemt. Het hoge aantal bacteriën in de vegetatie $(108-109 / g)$ is ook het gevolg van het ontbreken van fagocyterende leukocyten in dergelijke vegetaties.

Net als subacute natieve endocarditis ontstaat late prothetische endocarditis doordat bacteriën die in de bloedbaan zijn terechtgekomen, zich aan beschadigd endocard of aan vegetaties op of aan de klepprothese hechten. Bij subacute natieve endocarditis en late prothetische endocarditis worden ook vrijwel dezelfde verwekkers gevonden. Een vroege prothetische endocarditis ontstaat doordat bacteriën, met name S.epidermidis, de prothese besmetten tijdens of kort na de operatie. $\mathrm{Na}$ de operatie is de bacteriëmie meestal het gevolg van een gekoloniseerde intravasale katheter of van een postoperatieve wondinfectie.

\section{Epidemiologie}

Endocarditis heeft een incidentie van 2-3 gevallen per 100.000 personen per jaar. Dat betekent dat er in Nederland jaarlijks 200-450 gevallen van endocarditis zijn. In grotere ziekenhuizen zijn er gemiddeld 1-3 endocarditispatiënten per 1000 opnamen. De frequentie van deze infectieziekte is niet afgenomen toen antibiotica beschikbaar kwamen. In de tijd dat behandeling 
met antibiotica onmogelijk was, kwam endocarditis vooral bij jonge mensen voor. De gemiddelde leeftijd van patiënten met endocarditis ligt nu boven de 50 jaar. De 32-jarige patiënt GB behoort tot de leeftijdsgroep van 30-60 jaar, waarin nu meer dan de helft van alle gevallen van endocarditis voorkomt. Endocarditis komt bijna tweemaal vaker voor bij mannen dan bij vrouwen.

Hoe komt het dat endocarditis tegenwoordig bij ouderen vaker voorkomt dan bij jongeren? Een belangrijke oorzaak is dat er nu andere voor endocarditis predisponerende hartafwijkingen zijn dan vroeger. Vijftig jaar en langer geleden kwam endocarditis vooral voor bij patiënten die verworven hartafwijkingen hadden ten gevolge van acuut reuma: dit betrof $40-75 \%$ van alle endocarditispatiënten. Acuut reuma is een aandoening die twee tot drie weken na Streptococcus pyoge$n e s$-infecties ontstaat, voornamelijk bij kinderen en jonge volwassenen. Deze aandoening, vrijwel altijd gepaard gaand met een ontsteking van het endocard, komt in de westerse wereld bijna niet meer voor. Predisponerende afwijkingen voor endocarditis zijn nu vooral aangeboren hartafwijkingen en hartafwijkingen die op oudere leeftijd ontstaan. Door de vergrijzing neemt het aantal mensen met atherosclerotische hartklepgebreken toe, en is ook het aantal ouderen met kunstkleppen in het hart sterk gestegen. Een andere predisponerende aandoening voor endocarditis is een prolaps met insufficiëntie van de mitralisklep- pen, die vooral bij 40- tot 60 -jarigen voorkomt. Een andere factor is dat bij ouderen meer dan bij jongeren medische ingrepen worden verricht die gepaard gaan met een transiënte bacteriëmie (zie tabel 12.3). Ook infecties waardoor een transiënte bacteriëmie kan ontstaan, komen meer bij ouderen dan bij jongeren voor. Bij i.v.-drugsgebruikers komt endocarditis vaker voor dan bij leeftijdsgenoten. Bij deze groep betreft het in meer dan de helft van de gevallen een rechtszijdige endocarditis waarbij de tricuspidalisklep wordt aangetast. Een predisponerende hartafwijking is slechts bij een minderheid van de i.v.-drugsgebruikers met endocarditis aanwezig.

Endocarditis blijft een ernstige ziekte. Voordat antimicrobiële middelen beschikbaar waren, overleed iedereen aan de ziekte. $\mathrm{Nu}$ is de letaliteit van subacute natieve endocarditis door viridans-streptokokken $<10 \%$, maar de letaliteit van acute prothetische endocarditis is, ondanks antibacteriële therapie, $50-70 \%$.

\section{Klinische verschijnselen}

De eerste klinische verschijnselen van patiënt GB, zoals koorts, malaisegevoel, gebrek aan eetlust en gewichtsverlies, zijn weinig kenmerkend voor endocarditis, zodat vaak niet aan subacute endocarditis wordt gedacht $\mathrm{Bij}$ patiënten met subacute endocarditis zijn de klinische verschijnselen en afwijkingen (tabel 12.4) terug te voeren op vijf factoren:

Tabel 12.4 Symptomen en afwijkingen bij subacute endocarditis in volgorde van belangrijkheid.

\begin{tabular}{|c|c|c|c|c|}
\hline symptomen & $\%$ & & afwijkingen & $\%$ \\
\hline koorts & 80 & hart & souffles t.g.v. vegetaties & 85 \\
\hline malaisegevoel & 40 & huid & Osler-knobbeltjes & 20 \\
\hline anorexie & 25 & & splinterbloedingen & 15 \\
\hline gewichtsverlies & 25 & & petechiën & 30 \\
\hline nachtzweten & 25 & & andere & 20 \\
\hline hoofdpijn & 20 & nier & focale glomerulonefritis & 20 \\
\hline spierpijn & 20 & & diffuse glomerulonefritis & 10 \\
\hline pijn in gewrichten & 20 & & acute insufficiëntie & 5 \\
\hline pijn op de borst & 20 & hersenen & cerebrale embolieën & 15 \\
\hline buikpijn & 20 & & mycotisch aneurysma & 10 \\
\hline \multirow[t]{2}{*}{ rugpijn } & 10 & diverse organen & embolie, infarcering of & \\
\hline & & & mycotische aneurysmata & 10 \\
\hline
\end{tabular}


- de infectie in de vegetatie op het endocard van het hart;

- de continue bacteriëmie met de vorming van circulerende immuuncomplexen;

- het loslaten van thrombi (stolsels) van de vegetatie, waardoor perifere (micro-)embolieën in arteriën ontstaan;

- het ontstaan van metastatische infecties: dit zijn infecties die in diverse organen en weefsels ontstaan door de continue bacteriëmie en geïnfecteerde (micro-)embolieën;

- de schade aan het hart door de infectie.

Tegen de aanwezige bacteriën in de bloedbaan ontstaan antistoffen waardoor immuuncomplexen worden gevormd. De circulerende immuuncomplexen stranden in het capillairbed van weefsels en organen. In de capillairen ontstaat daardoor een vasculitis, een steriele ontsteking van de bloedvaten. Veel van de klinische manifestaties als gewrichtspijn en afwijkingen in de huid zoals Osler-knobbeltjes, splinterbloedingen en petechiën in het mondslijmvlies en de conjunctiva, afwijkingen in de oogfundus (Roth's spots), splenomegalie (vergrote milt), nierafwijkingen en cerebrale beschadigingen zijn toe te schrijven aan de depositie van immuuncomplexen (tabel 12.4).

In de nier ontstaat door het afzetten van de immuuncomplexen in de glomeruli al vroeg in de ziekte een glomerulonefritis. De microscopische hematurie en het licht verhoogde serumcreatinine bij patiënt GB waren de eerste manifestaties van een lokale (focale) glomerulonefritis. De ernst van de nierafwijkingen is gerelateerd aan de duur van de ziekte. Bij langer durende subacute endocarditis ontstaat er een diffuse proliferatieve glomerulonefritis, die kan leiden tot een acute nierinsufficiëntie. Dan zijn er bij onderzoek van de urine in het sediment cilinders (afgietsels van de tubuli) aanwezig.

Bij patiënten met linkszijdige endocarditis veroorzaken embolieën, losgelaten van de vegetaties, een infarcering in diverse organen en weefsels. De grootte van de vegetaties heeft voorspellende waarde voor het optreden van embolieën. Embolieën komen vooral voor in de coronairvaten van het hart, de bloedvaten van nieren, milt en hersenen en bevatten meestal bacteriën (septische embolie). Toch zijn - anders dan bij acute endocarditis - bij subacute endocarditis metastatische infecties zeldzaam. Het aantal bacteriën, meestal van een weinig virulente soort, is te gering om elders een infectie te doen ontstaan, behalve van een door vasculitis beschadigde vaatwand; een dergelijke infectie van een vaatwand wordt aangeduid met de term mycotisch aneurysma en komt vooral voor in hersenvaten, de aorta, coronairvaten en miltarteriën. Neurologische symptomen (hoofdpijn, verlammingen) zijn meestal het gevolg van cerebrale embolieën en van vasculitis en mycotische aneurysmata van de hersenvaten. De meest voorkomende complicaties van het hart zijn een klepperforatie of ruptuur van een hartklep en een afgebroken chorda tendinea. Dan kan een acute hemodynamische complicatie ontstaan, die alleen met snel cardiochirurgisch ingrijpen is te verhelpen.

\section{Diagnose}

De diagnose bij patiënt GB, subacute natieve endocarditis door S.sanguis, werd gesteld op grond van het klinisch beloop van de ziekte, de klinische verschijnselen, de bevindingen van de bloedkweek en het echocardiografisch onderzoek.

Het aantal bacteriën in de bloedbaan is betrekkelijk laag. Daarom worden voor het aantonen van bacteriëmie ten minste drie bloedkweken afgenomen. Voor de diagnose subacute endocarditis is het noodzakelijk dat in de verschillende bloedkweken hetzelfde micro-organisme groeit.

Bij $>90 \%$ van de patiënten wordt de verwekker van de endocarditis uit het bloed gekweekt. Indien de bloedkweken negatief blijven, kan er sprake zijn van een bloedkweek-negatieve endocarditis. Dit komt vooral voor bij patiënten die vooraf antibiotica hebben gekregen. Bij hen moeten de bloedkweken worden herhaald. Sommige verwekkers van endocarditis groeien echter niet goed of in het geheel niet in de gebruikelijke bloedkweekmedia. Voor schimmels en bacteriën, zoals Legionella pneumophila, Chlamydia, Mycoplasma, Brucella en Coxiella burnetii, berust de diagnose op serologisch onderzoek van het bloed en op andere (moleculair-biologische) technieken. 
Voor het aantonen van de vegetaties en de hartafwijkingen wordt gebruikgemaakt van transthoracale of transoesofageale echocardiografie. De laatste methode is het gevoeligst.

Voor de diagnose endocarditis zijn criteria (volgens Duke) opgesteld waarmee in de praktijk de diagnose endocarditis zeker respectievelijk waarschijnlijk is te stellen of moet worden verworpen (tabel 12.5).

\section{Behandeling}

Antibiotica zijn onontbeerlijk voor de behandeling van patiënten met endocarditis. Patiënt GB voelde zich zelfs al beter nadat de huisarts amoxicilline had voorgeschreven; dit kwam doordat de S.sanguis er gevoelig voor was. De bacteriëmie verdwijnt dan snel. De bloedkweken worden negatief, maar de vegetaties op de aortakleppen bevatten nog grote aantallen levende bacteriën. De endocarditis is nog niet genezen. In de vegetatie liggen de bacteriën ingekapseld in het fibrine-bloedplaatjesnetwerk. In de diepere lagen zijn onvoldoende voedingstoffen beschik- baar en is de groeisnelheid van bacteriën laag, waardoor ook hun gevoeligheid voor een groot aantal antibiotica afneemt; de meeste antibiotica grijpen immers aan in processen die betrokken zijn bij de deling en vermenigvuldiging van bacteriën en de celwandsynthese (bijv. penicilline). Om deze reden en vanwege het ontbreken van leukocyten in de vegetaties moeten patiënten met een endocarditis altijd worden behandeld met antibiotica die een bactericide effect hebben bacteriostatische middelen hebben geen genezend effect - en moet de behandeling langdurig zijn. Het type endocarditis en de ernst van de infectie en de complicaties bepalen de behandelingsduur. Patiënten met endocarditis worden ten minste twee, maar meestal vier weken behandeld; soms is een behandeling van zes weken of langer nodig. De antibiotica worden in een hoge dosis parenteraal gegeven om er zeker van te zijn dat de concentratie ervan in de bloedbaan hoog genoeg is om in de moeilijk doordringbare vegetatie een bactericide effect te bewerkstelligen. Voor de juiste keuze van de antibiotica is het es-

Tabel 12.5 Diagnose van endocarditis en de Duke-criteria.

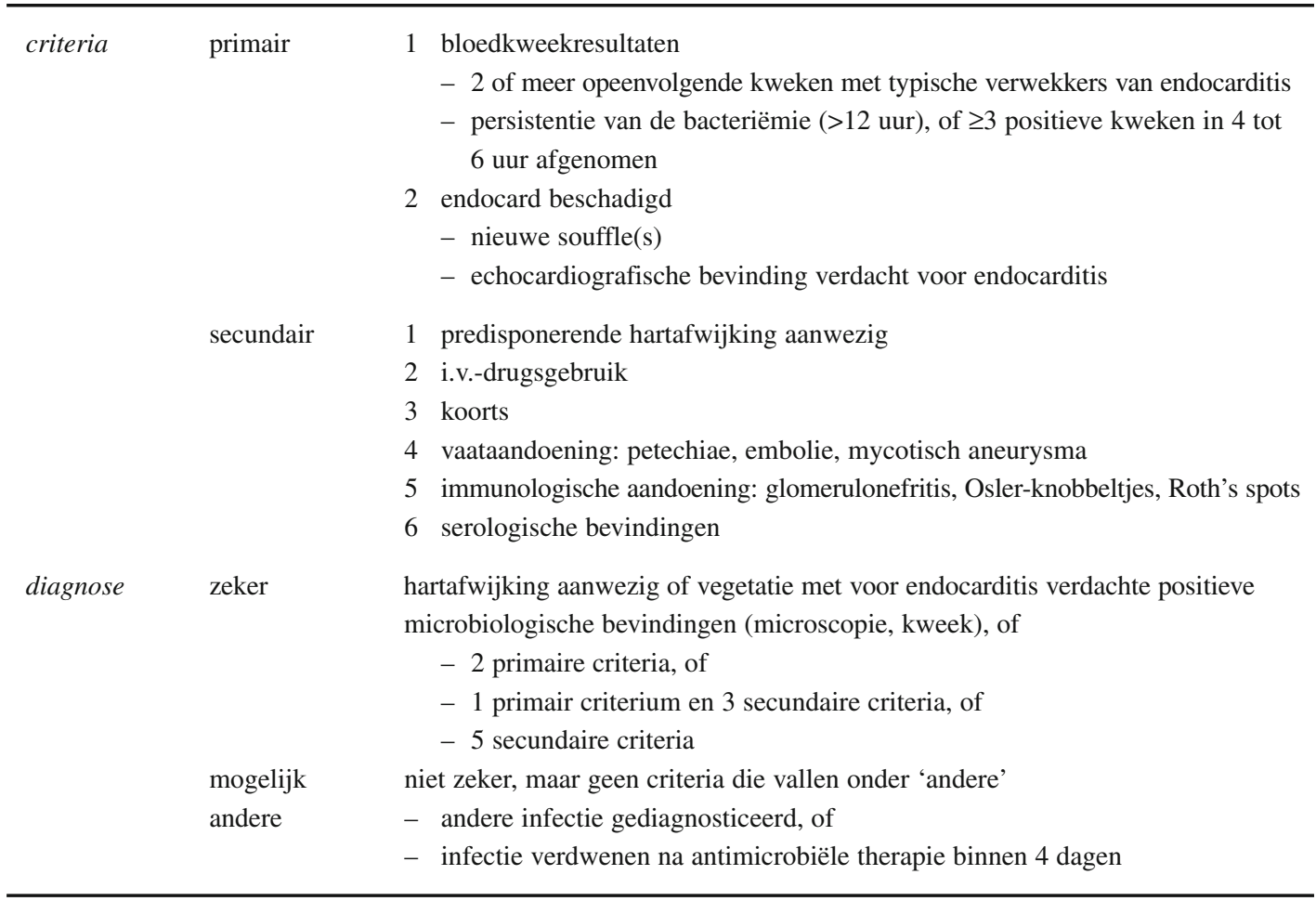


sentieel dat in het medisch microbiologisch laboratorium de minimaal bactericide concentraties van diverse middelen voor de uit het bloed geïsoleerde verwekker worden vastgesteld. Patiënt GB werd eerst behandeld met penicilline en gentamicine. S.sanguis, uit zijn bloedkweken geïsoleerd, was goed gevoelig voor penicilline. Hoewel viridans-streptokokken niet goed gevoelig zijn voor gentamicine, heeft de combinatie penicilline en gentamicine een synergistisch bactericide effect op deze bacteriën: ze worden veel sneller gedood door deze twee middelen samen te geven dan door een van beide apart. De resultaten van behandeling van patiënten met kweek-negatieve endocarditis zijn meestal slechter dan die bij patiënten met endocarditis waarvan de verwekker is geïsoleerd. Als de micro-organismen resistent zijn of als de endocarditis wordt veroorzaakt door schimmels of gisten, is het nodig de geïnfecteerde hartklep te vervangen door een klepprothese. Ook patiënten die door de infectie ernstige schade aan het hart hebben, waardoor decompensatio cordis is ontstaan, worden geopereerd en krijgen een hartklepprothese.

\section{Preventie}

Patiënten met bepaalde aangeboren of verworven hartafwijkingen hebben een verhoogd endocarditisrisico als bij hen diagnostische, tandheelkundige of operatieve ingrepen worden verricht waarbij een bacteriëmie ontstaat (tabel 12.3). Hoewel er geen gecontroleerde onderzoeken zijn waarin het effect van de antimicrobiële profylaxe voor de preventie van endocarditis is vastgesteld, is in dierexperimenteel onderzoek aangetoond dat profylaxe met een bactericide antibioticum endocarditis kan voorkomen. Hoewel de bacteriëmie zelf niet wordt voorkomen door de antimicrobiële profylaxe, worden de op de vegetaties gehechte bacteriën in een vroeg stadium gedood. Voor de endocarditisprofylaxe bestaan richtlijnen die in ons land worden uitgegeven door de Nederlandse Hartstichting.

\section{Verwekkers van subacute endocarditis}

S.sanguis, geïsoleerd bij patiënt GB, behoort tot de vergroenende of viridans-streptokokkengroep (viridis, Latijn voor groen), die bij het merendeel van alle gevallen van subacute natieve endocarditis wordt geïsoleerd uit het bloed. Viridans-streptokokken worden ook aangeduid als $\alpha$-hemolytische streptokokken (groei op een bloedplaat in het laboratorium veroorzaakt een vergroening door aantasting van de erytrocyten). Deze groene zone, een gevolg van partiële lysis van erytrocyten en oxidatie van hemoglobine tot methemoglobine, wordt ook door S.pneumoniae (pneumokokken) gevormd. Streptokokkensoorten die de erytrocyten volledig lyseren, waardoor een heldere zone rondom de kolonies op een bloedagarplaat ontstaat (de $\beta$-hemolyse), worden als $\beta$-hemolytische streptokokken aangeduid. Sommige streptokokkensoorten behoren tot de groep indifferente ( $\gamma$-hemolytische) streptokokken (dan is er geen enkele reactie met de erytrocyten).

Viridans-streptokokken zijn net als de andere streptokokken, Gram-positieve kokken die in ketens liggen (fig. 12.5). De diverse soorten viridans-streptokokken komen in de normale residente microflora op het slijmvlies in de mondkeelholte voor. Ongeveer de helft van het aantal bacteriën in de mond-keelholte zijn viridansstreptokokken. Sommige soorten viridans-streptokokken zijn vooral te vinden op het wangslijmvlies: S.sanguis en S.mitis. Op de tong worden met name S.sanguis en S.salivarius gevonden, terwijl op en in de tandplaque S.sanguis, S.oralis en S.mutans voorkomen. Het speeksel bevat vooral S.salivarius, S.oralis en S.mitis.

De verdeling zoals gegeven berust niet op toeval, maar is een gevolg van specifieke bacteriële structuren en weefselreceptoren waarmee hechting tussen de bacteriën tand- en weefseloppervlak totstandkomt.

Subacute natieve endocarditis wordt behalve door viridans-streptokokken ook door andere, eveneens weinig virulente bacteriesoorten veroorzaakt. Het betreft veelal ook Gram-positieve kokken, zoals S.bovis en enterokokken (Enterococcus spp.) (tabel 12.6). S.epidermidis, een coagulase-negatieve stafylokokkensoort, is een veelvoorkomende verwekker van vroege prothetische endocarditis, met meestal een klinisch geprotraheerd beloop. S.epidermidis is slechts zelden de oorzaak van een subacute natieve endocarditis. Virulente, invasieve bacteriën, met name S.au- 


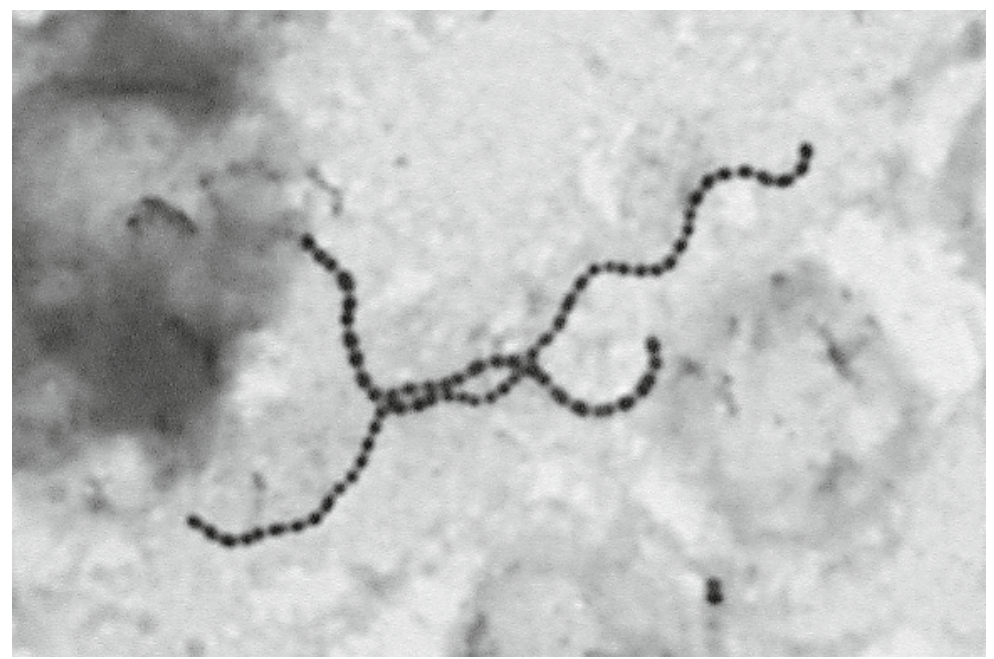

Figuur 12.5 Viridans-streptokokken in een bloedkweek van een patiënt met endocarditis: Gram-positieve, bolvormige bacteriën die in ketens liggen.

reus, veroorzaken acute vormen van endocarditis. S.aureus is ook de meest frequente verwekker van endocarditis bij i.v.-drugsgebruikers. In 75\% van de gevallen is er bij hen sprake van een rechtszijdige natieve endocarditis, waarvan het ziektebeloop milder is dan dat van linkszijdige endocarditis. S.aureus kan endocarditis veroorzaken zonder dat er sprake is van enige predisponerende hartafwijking.

\subsubsection{Acute endocarditis}

Acute endocarditis verschilt aanzienlijk van subacute endocarditis, zowel wat betreft de aard van de verwekkers als het beloop en de prognose. Bij $60-70 \%$ van de gevallen van acute natieve of prothetische endocarditis is S.aureus de verwekker. Acute endocarditis wordt gekarakteriseerd door hoge koorts en andere septische verschijnselen. De patiënt zal, als geen effectieve behandeling wordt gegeven, binnen enkele dagen tot weken aan de infectie overlijden.

Tabel 12.6 Procentuele verdeling van de verwekkers van natieve en prothetische endocarditis.

\begin{tabular}{|c|c|c|c|c|}
\hline \multirow[t]{2}{*}{ verwekker } & \multicolumn{2}{|c|}{ natieve endocarditis } & \multicolumn{2}{|c|}{ prothetische endocarditis } \\
\hline & totaal $^{1}$ & $\begin{array}{l}\text { intraveneuze } \\
\text { drugs- } \\
\text { gebruikers }\end{array}$ & $\begin{array}{l}\text { vroeg } \\
(\leq 1 \text { jaar na } \\
\text { operatie })\end{array}$ & $\begin{array}{l}\text { laat } \\
\text { (>1 jaar na } \\
\text { operatie) }\end{array}$ \\
\hline viridans-streptokokken & $50-60$ & 10 & 5 & $30-35$ \\
\hline Streptococcus bovis & $5-10$ & $1-5$ & $1-5$ & 5 \\
\hline andere streptokokken & $1-5$ & $1-5$ & $1-5$ & $1-5$ \\
\hline Enterococcus spp. & 10 & 10 & $1-5$ & 10 \\
\hline Staphylococcus aureus & 30 & 60 & 10 & 15 \\
\hline coagulase-negatieve stafylokokken & 5 & $1-5$ & 55 & 10 \\
\hline andere bacteriesoorten & $5-10$ & 10 & 5 & $5-15$ \\
\hline gisten/schimmels & 1 & 5 & 5 & $<1$ \\
\hline kweek negatief & $1-5$ & 5 & 10 & 5 \\
\hline
\end{tabular}

1 Alle patiënten, incl. i.v.-drugsgebruikers. 


\section{casus 2}

Mevrouw AS, 48 jaar, werd met spoed opgenomen vanwege ernstig ziek zijn, met hoge koorts en koude rillingen. Twee dagen eerder thuiskomend van haar werk als manager in een winkel had ze zich ziek gevoeld met spier- en gewrichtspijn. Ze was altijd gezond geweest. Bij opname werd een bleke, acuut zieke vrouw gezien. Haar lichaamstemperatuur was $39,8^{\circ} \mathrm{C}$, de hartfrequentie was 125/min., de bloeddruk was $100 / 60 \mathrm{mmHg}$ en haar ademhalingsfrequentie was 40/min.

Bij lichamelijk onderzoek werden geen afwijkingen gevonden. De harttonen waren normaal. Op een thoraxfoto werden geen afwijkingen van hart en longen gezien. Bij het laboratoriumonderzoek bleken de bezinkingssnelheid en het leukocytenaantal sterk verhoogd en was het trombocytenaantal verlaagd. Onderzoek van de urine toonde een lichte proteïnurie, erytrocyturie en een pyurie aan; bacteriën werden niet gezien. Er werden bloedkweken genomen. Patiënte kreeg een infuus en op verdenking van een sepsis werd ze behandeld met flucloxacilline en gentamicine.

De volgende dag voelde zij zich al wat beter. De bloedkweek was gegroeid en verdacht voor stafylokokken. Een dag later groeiden op de beënte bloedplaten gele kolonies met een hemolytische hof: S.aureus. De therapie werd gecontinueerd met alleen flucloxacilline.

De volgende dag bleef de temperatuur subfebriel $\left(38^{\circ} \mathrm{C}\right)$, en op de vierde dag klaagde patiënte over een drukkende hoofdpijn en was ze verward. Bij neurologisch onderzoek werden geen afwijkingen gevonden. Een ст van het hoofd toonde in de hersenen rechts pariëtaal een ruimte-innemend proces met een diameter van ongeveer $1,5 \mathrm{~cm}$. Op verdenking van een metastatisch cerebraal abces werd de antimicrobiële therapie uitgebreid met rifampicine (een antibioticum dat bactericide is voor stafylokokken en goed penetreert in abcessen).

Twee dagen later werd bij auscultatie een graad III/VI systolisch geruis aan de punt van het hart gehoord met een luide tweede toon, verdacht voor een mitralisinsufficiëntie. Echocardiografisch onderzoek toonde verdikte mitraliskleppen zonder vegetatie; het linkeratrium was overvuld. In de volgende dagen verbeterde de klinische toestand van de patiënte langzaam, hoewel de temperatuur $38^{\circ} \mathrm{C}$ bleef, op de rechtervoetzool en de linkerhand petechiae waren ontstaan en de patiënte over ademnood (dyspneu) begon te klagen. De bloedkweken afgenomen tijdens therapie waren negatief, op één na, waaruit S.aureus groeide. op grond van de verdenking op acute natieve mitralisklependocarditis door S.aureus met een metastatische infectie in cerebro en vanwege de decompensatio cordis ten gevolge van de mitralisklepinsufficiëntie werd tot openhartchirurgie overgegaan. Bij operatie bleek op één van de mitraliskleppen een kleine vegetatie aanwezig, een andere klep was geperforeerd. De mitralisklep werd vervangen door een prothese. Uit de klep, die werd ingestuurd voor kweek, werd S.aureus gekweekt, gevoelig voor flucloxacilline en rifampicine. De antimicrobiële therapie werd gecontinueerd gedurende acht weken. Bij naonderzoek werd vastgesteld dat patiënte diabetes mellitus had. Een halfjaar na ontslag heeft zij voor halve dagen haar werk hervat.

\section{Pathogenese}

Mevrouw AS werd opgenomen met een ernstige sepsis, veroorzaakt door S.aureus. De bron van de sepsis was bij opname niet duidelijk. Er was geen lokale infectiehaard aanwezig van waaruit het micro-organisme de bloedbaan had bereikt. Maar waar komen de bacteriën dan vandaan? S.aureus komt bij 30\% van de mensen voor; zij zijn dragers van S.aureus. Bij dragers wordt de bacterie gevonden in de voorste neuskamers en op het slijmvlies in de keel en in het maag-darmkanaal. Bij diabetici komt S.aureus-dragerschap vaker voor. $\mathrm{Bij}$ 80-90\% van de gevallen waarin een acute S.aureus-endocarditis ontstaat, wordt geen porte d'entrée voor de bacteriëmie gevonden. Wat dat betreft is patiënte AS dus geen uitzondering. 


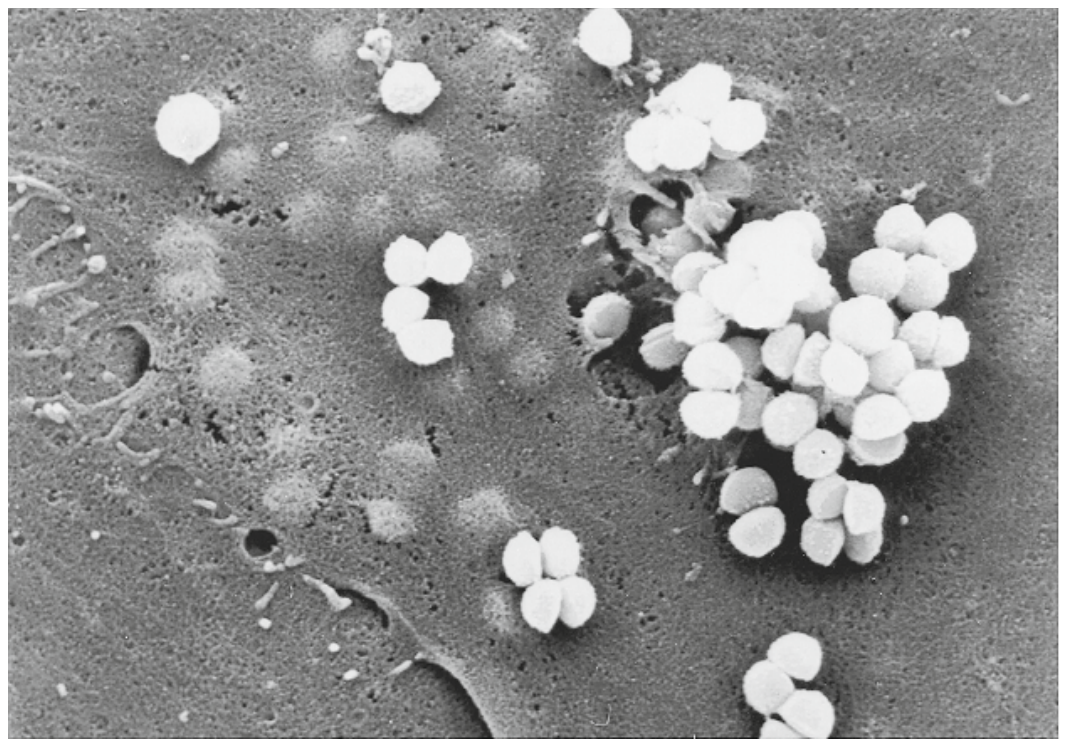

Figuur 12.6 Elektronenmicroscopische scan van de hechting van S.aureus aan endotheelcellen. Op de linkerhelft zijn gehechte bacteriën door de endotheelcellen opgenomen.

Hoe is bij deze tevoren gezonde vrouw die tot dan geen hartafwijkingen had, de endocarditis ontstaan? De endocarditis door S.aureus ontstaat op twee verschillende manieren. Bij ongeveer de helft van de patiënten met natieve S.aureus-endocarditis hecht de bacterie zich aan reeds op het endocard aanwezige vegetaties, die door hartafwijkingen met een Venturi-effect zijn ontstaan, net als bij de subacute endocarditis van patiënt GB. Bij hen zijn bij opname al afwijkende hartgeruisen te horen. Hoe ontstaat bij de andere helft van de patiënten, die van te voren geen aantoonbare hartafwijkingen, hebben dan de endocarditis? S.aureus is een van de weinige bacteriesoorten die zich goed aan normale endotheelcellen kunnen hechten. Na hechting worden de bacteriën opgenomen door de endotheelcellen (fig. 12.6), die daarna lyseren ten gevolge van door S.aureus geproduceerde toxinen, waarna de bacteriën andere cellen en het onderliggende weefsel invaderen. In het subendotheliale weefsel ontstaan door de lysis van cellen micro-abcessen. Bij patiënte AS werd bij de operatie een dergelijk abces uitgeruimd. Door activatie van stollingsfactoren vormt zich op het beschadigde endotheel vervolgens een fibrine-bloedplaatjesnetwerk of een vegetatie. S.aureus is in de vegetatie beschermd tegen fagocytose door leukocyten. De lichaamstemperatuur blijft door de aanwezigheid van metabool actieve bacteriën in vegetaties, abcessen en bloedbaan onrustig, en er ontstaan metastatische infecties door septische embolieën vanuit vegetaties op het endocard van de mitralisklep. Bij deze patiënte waren metastatische infecties in de hersenen en later in de huid aanwezig, maar zij kunnen ook in de milt, nieren, gewrichten of botten ontstaan. Waarom niet iedereen met S.aureus-bacteriëmie ook endocarditis krijgt, is niet bekend.

\section{Epidemiologie}

S.aureus-endocarditis ontstaat in aansluiting op een bacteriëmie met S.aureus. Er zijn drie groepen waarbij de frequentie van S.aureus-infecties, bacteriëmie en sepsis hoog is: hemodialysepatiënten, patiënten met diabetes mellitus en i.v.drugsgebruikers. Zij hebben daardoor ook een verhoogd risico voor S.aureus-endocarditis, evenals ouderen en patiënten met een hartklepprothese. De helft van de patiënten met S.aureusbacteriëmie en sepsis krijgt de infectie buiten het ziekenhuis, net als patiënte AS. Bij slechts enkelen van hen gaat aan het ontstaan van de bacteriëmie en sepsis een andere S.aureus-infectie vooraf, zoals een steenpuist (furunkel) of een wondinfectie. In het ziekenhuis ontstaat S.aureusbacteriëmie en sepsis dikwijls vanuit met S.aureus geïnfecteerde operatiewonden en gekoloni- 
seerde intravasale katheters. Van alle patiënten met S.aureus-bacteriëmie en sepsis krijgt 20$30 \%$ endocarditis. Opvallend is dat patiënten met S.aureus-endocarditis meestal patiënten zijn bij wie de bacteriëmie buiten het ziekenhuis is ontstaan zonder dat een porte d'entrée voor een bacteriëmie aantoonbaar is. Bij i.v.-drugsgebruikers is S.aureus de meest voorkomende verwekker van endocarditis (zie tabel 12.6). Er is dan vrijwel altijd een rechtszijdige natieve endocarditis waarbij de tricuspidaliskleppen zijn geïnfecteerd. In $75-85 \%$ van de gevallen is geen predisponerende hartafwijking voor endocarditis en geen andere S.aureus-infectiehaard aanwezig. Geschat wordt dat per jaar 1-2 gevallen van endocarditis per 1000 i.v.-drugsgebruikers voorkomen.

In het algemeen is de letaliteit van natieve linkszijdige endocarditis door S.aureus hoog (20$30 \%$ ). Voor i.v.-drugsgebruikers met rechtszijdige endocarditis is de letaliteit ongeveer 2-6\%. Van de HIV-positieve i.v.-drugsgebruikers met S.aureus-endocarditis overlijdt echter $30 \%$. Patiënten met prothetische endocarditis door S.aureus hebben de slechtste prognose; van hen overlijden de meesten.

\section{Klinische verschijnselen}

Patiënte AS met een acute natieve linkszijdige endocarditis door S.aureus, had bij opname een ernstige sepsis ten gevolge van S.aureus-bacteriëmie. Bij opname waren de harttonen normaal. Dat is bij de helft van de gevallen met linkszijdige S.aureus natieve endocarditis het geval. Verschijnselen van endocarditis ontstaan pas enkele dagen later. Dan pas kunnen ook met echocardiografisch onderzoek vegetaties en andere afwijkingen van de hartkleppen worden aangetoond. Welke verschijnselen wezen er bij deze patiënte op dat zich bij haar een endocarditis ontwikkelde? De eerste aanwijzing daarvoor is het subfebriel blijven van de temperatuur, terwijl ze al enkele dagen werd behandeld met antibiotica waarvoor de geïsoleerde S.aureus gevoelig was. Het cerebraal abces en de petechiae in de huid waren ook aanwijzingen voor een primaire intravasale infectie bij patiënte AS. Metastatische infecties zijn een kenmerk van S.aureus-endocarditis en ontstaan bij meer dan $50 \%$ van de patiënten. Ten slotte wezen de acute klachten van de decompensatio cordis op destructie van de mitraliskleppen. Op grond van de verschijnselen en het klinisch beloop was het noodzakelijk patiënte AS acuut te opereren. Bij haar was dit de enige mogelijkheid om de infectie te genezen. De klinische verschijnselen van patiënte $A S$ en patiënt GB verschillen derhalve op veel punten. Daaruit blijkt het klinische verschil tussen acute en subacute endocarditis.

Bij i.v.-drugsgebruikers met rechtszijdige S.aureus-endocarditis is het klinisch beloop nog heel anders dan bij patiënte AS, al hebben ze bij opname net als patiënte AS meestal ook hoge koorts en klagen ze over spierpijn en gewrichtspijn. Op de voorgrond staan bij deze patiënten echter longklachten: zij hoesten en hebben pijn bij ademhalen. Dit wordt veroorzaakt door de longafwijkingen ten gevolge van embolieën die van de tricuspidaliskleppen loslaten en in het longvaatbed stranden. Bij auscultatie van de longen zijn de bevindingen meestal normaal, maar op een thoraxröntgenfoto worden veel diffuse vlekjes (het beeld van een sneeuwstorm) gezien. S.aureus is ook een belangrijke verwekker van prothetische endocarditis, zowel in het eerste jaar na de operatie (vroege prothetische endocarditis) als daarna (late prothetische endocarditis) (zie tabel 12.6). Het klinisch beeld heeft een fulminant beloop, net als de linkszijdige natieve $S . a u$ reus-endocarditis van patiënte AS.

\section{Diagnose}

De diagnose van S.aureus-endocarditis bij patiënten met kunsthartkleppen of een hartafwijking wordt gesteld conform de eerder genoemde criteria van Duke (tabel 12.5). Bij patiënten zoals mevrouw AS, die geen predisponerende hartafwijkingen had, is de diagnose veel moeilijker te stellen. Een belangrijk probleem voor de diagnostiek is dat bij opname geen onderscheid kan worden gemaakt tussen S.aureus-bacteriëmie met en zonder endocarditis. Het verschil ontstaat pas tijdens antimicrobiële therapie. De S.aureus-bacteriëmie met endocarditis blijft langer aanhouden dan bij patiënten zonder endocarditis. Daarom is het nodig bij alle patiënten met S.aureus-bacteriëmie de bloedkweken in het begin van de therapie 
dagelijks te herhalen. Een positieve bloedkweek tijdens de therapie is een sterke aanwijzing voor een intravasale infectie.

Een ander probleem bij de diagnose van linkszijdige acute endocarditis is dat bij 30-45\% van de patiënten bij opname hartgeruisen ontbreken. Nauwkeurige en herhaalde auscultatie van het hart is van het grootste belang, want in geval van S.aureus-endocarditis ontstaan na verloop van tijd door de hartklepdestructie bij de meeste patiënten hartgeruisen. Bij i.v.-drugsgebruikers met rechtszijdige natieve S.aureus-endocarditis ontbreken bij opname de hartgeruisen in vrijwel alle gevallen; bij slechts de helft van deze patiënten ontstaan hartgeruisen in de loop van de ziekte. Een initiële negatieve bevinding sluit endocarditis dus geenszins uit.

\section{Therapie}

S.aureus-endocarditis dient als een gegeneraliseerde infectieziekte te worden beschouwd, vanwege het hoge percentage patiënten bij wie zich metastatische infecties ontwikkelen. Voor de behandeling van de endocarditis wordt uitgegaan van dezelfde principes als vermeld voor de subacute endocarditis: bactericide antibiotica, voldoende hoge bloedspiegels en een lange behandelingsduur. De meeste patiënten met natieve S.aureus-endocarditis worden met flucloxacilline behandeld. Bij prothetische S.aureus-endocarditis wordt nooit monotherapie toegepast. De behandeling - meestal een combinatie van flucloxacilline en gentamicine - duurt vrijwel altijd langer dan zes weken.

Bij alle vormen van acute endocarditis is hartchirurgie een belangrijk onderdeel van de therapie. Rond $30 \%$ van de patiënten met linkszijdige acute natieve endocarditis en $80 \%$ van de patiënten met acute prothetische endocarditis komen hiervoor in aanmerking. Belangrijke indicaties voor acute chirurgie zijn persisterende bacteriëmie, twee of meer ernstige manifestaties, septische embolieën, progressieve hartinsufficiëntie (decompensatio cordis), en het optreden van hartgeleidingsstoornissen doordat de infectie zich uitbreidt naar het septum. Dit gebeurt vooral bij acute endocarditis van de aortakleppen. Tijdens en na operatie worden de antibiotica gecontinueerd.

\section{Preventie}

Hoe kan S.aureus-endocarditis worden voorkomen? Bij patiënten die voor endocarditis predisponerende hartafwijkingen en een gelokaliseerde S.aureus-infectie hebben, wordt volgens de richtlijnen van de Nederlandse Hartstichting voor de ingreep flucloxacilline gegeven. Patiënte AS kreeg spontaan een bacteriëmie door S.aureus. Dat risico is bij iedere S.aureus-drager aanwezig. Vaccinatie tegen S.aureus verkeert nog in een experimenteel stadium. Een andere mogelijkheid zou zijn dragers van S.aureus (zie verder) te behandelen met het antibioticum mupirocine, dat als zalf in de neus kan worden aangebracht. Onderzoek heeft uitgewezen dat bijna alle $S$.aureus-dragers negatief worden na vijf dagen behandeling met muporicine-neuszalf, en weken tot maanden daarna negatief blijven. Bij nierdialysepatiënten en openhartchirurgiepatiënten heeft dit beleid geleid tot een vermindering van S.aureusinfecties. Over het effect van eliminatie van het S.aureus-dragerschap op het voorkomen van endocarditis zijn echter nog geen gegevens bekend.

\section{Andere verwekkers van acute endocarditis}

Behalve S.aureus, de meest voorkomende verwekker, kan acute endocarditis ook worden veroorzaakt door S.pneumoniae, $\beta$-hemolytische streptokokken (o.a. S.pyogenes: Streptococcus groep A), S.agalactiae (Streptococcus groep B) en Streptococcus groep G, Neisseria gonorrhoeae (gonokok) en diverse Gram-negatieve staven (Enterobacteriaceae en Pseudomonas aeruginosa). Acute prothetische endocarditis wordt door dezelfde verwekkers en door gisten en schimmels veroorzaakt. De belangrijkste verwekkers van vroege prothetische endocarditis zijn evenwel S.epidermidis en andere coagulasenegatieve stafylokokken.

\subsection{Infecties door S.aureus en coagulase-negatieve stafylokokken}

Acute endocarditis is slechts een van de vele infecties die door S.aureus worden veroorzaakt (tabel 12.7). De klinische verschijnselen en de 
Tabel 12.7 Infecties ten gevolge van Staphylococcus aureus.

huid en subcutaan weefsel

- impetigo

- furunkel (steenpuist); karbunkel

- cellulitis

- postoperatieve wondinfectie

- fijt en paronychium (van het laatste vingerkootje)

- mastitis puerperalis (borstklierinfectie)

longen

- abcederende longontsteking, bijv. na virale (influenza-)infectie

bloedbaan (meestal secundair t.g.v. één van de lokale infecties)

- bacteriëmie en sepsis of ernstige sepsis of MOF

inwendige organen, bot, gewrichten

- na trauma of na operatie

- hematogeen: t.g.v. in de bloedbaan circulerende S.aureus (metastatische infecties) in

- hersenen: abces, epiduraal abces

- hart: endocarditis

- bot: osteomyelitis

- gewrichten: artritis

- longen: longabces, empyeem (in pleuraholte)

- nieren: nierabces, nierkarbunkel

ernst van een S.aureus-infectie zijn afhankelijk van de plaats en het orgaan waar de S.aureus-infectie zich bevindt. Ruim $20 \%$ van de patiënten met een S.aureus-sepsis overlijdt ondanks toediening van antibiotica. Andere soorten stafylokokken, de coagulase-negatieve stafylokokken (CONS), zijn belangrijke verwekkers van ziekenhuisinfecties, vooral bij patiënten met een intravasale katheter of een kunststof implantaat (tabel 12.8).

\subsubsection{Stafylokokken: S.aureus en CONS}

Stafylokokken zijn Gram-positieve ronde bacteriën (diameter 0,8-1,2 mm), die in groepjes of trosjes (stafylos: druiventros) liggen. Het genus Staphylococcus omvat 32 verschillende stafylo- kokkensoorten, die morfologisch in het Grampreparaat niet onderscheiden kunnen worden. Daarvoor worden verschillende andere methoden gebruikt, onder meer de coagulasetest. Coagulase, een enzym dat plasma doet stollen, wordt alleen door S.aureus gevormd en uitgescheiden.

Op een bloedagarplaat gegroeid maakt S.aureus een geel pigment. Aan deze goudgele koloniekleur heeft S.aureus zijn naam te danken. Hemolytische exotoxinen van S.aureus lyseren erytrocyten, waardoor om de gele kolonies op een bloedagarplaat heldere hemolytische zones ontstaan. Kolonies van CONS gegroeid op een bloedagarplaat zijn glanzend wit en niet omgeven door een hemolytische hof. Klinisch belangrijke cONS zijn S.epidermidis, als verwekkers van ziekenhuisinfecties, en S.saprophyticus, als verwekker van urineweginfecties (tabel 12.8).

Tabel 12.8 Infecties ten gevolge van coagulase-negatieve stafylokokken (CONS).

\footnotetext{
infecties van kunststof implantaat

- hartkunstklep-endocarditis

- cerebrospinale vloeistof-shunts

- gewrichtsprothese

- hemodialyseshunts

- peritoneale-dialysekatheter

- pacemakerdraden en elektroden

- vaatprothese
}

infectie van intravasale katheter

- insteekopening

- bacteriëmie en sepsis

bacteriëmie, sepsis en ernstige sepsis bij patiënten met neutropenie

urineweginfecties

\subsubsection{Kolonisatie en dragerschap}

Stafylokokken komen voor in de microflora van de huid en op de slijmvliezen van mens en warmbloedige dieren. Door verlies van huidcellen, slijmvliescellen en haren worden stafylokokken ook in de omgeving van hun gastheren aangetroffen. Stafylokokken kunnen zich goed hand- 
haven in een droge omgeving, en komen voor in de lucht binnenshuis, in huisstof, op kleding en op oppervlakken van meubilair en voorwerpen. Dagelijks komen we zo in contact met stafylokken, maar ook bij handenschudden of andere wijzen van lichaamscontact dragen we stafylokokken over. Kort na de geboorte worden de huid en het slijmvlies van de mond-, neus- en keelholte van de pasgeborene al met stafylokokken besmet. S.epidermidis en andere CONS-soorten blijven bij iedereen gedurende het hele leven aanwezig in de residente microflora van de huid. S.aureus-besmetting van de pasgeborene vindt ook kort na de geboorte plaats. Binnen enkele dagen komt bij $60-80 \%$ van de zuigelingen de bacterie voor op de huid en de navel; met het klimmen van de leeftijd daalt het percentage kinderen dat gekoloniseerd is echter. Van de volwassenen is ongeveer $30 \%$ permanent drager van S.aureus, waarbij de voorste neuskamers (vestibulum nasi) de belangrijkste niche van deze bacteriesoort bij de mens zijn. Bij sommige dragers koloniseert de bacterie ook het slijmvlies van de keelholte en het maagdarmkanaal en de huid. Bij ongeveer 30-50\% van de volwassenen komt kolonisatie van de neus met S.aureus zo nu en dan gedurende korte tijd voor (intermitterend dragerschap). Dit betekent dat bij $20-40 \%$ van de mensen kolonisatie door deze bacterie niet optreedt (permanente niet-dragers). Waardoor mensen permanent of intermitterend of nooit drager van S.aureus worden, is niet bekend. Wel is bekend dat S.aureus-dragerschap vaker voorkomt bij personen met diabetes melli- tus, patiënten die gedialyseerd worden, personen met eczeem (atopische dermatitis), HIV-geïnfecteerden en i.v.-drugsgebruikers.

Verspreiding van S.aureus treedt op door direct contact, door contact met besmette goederen, kleding of voorwerpen en door lucht (fig. 12.7). Dragers met virale infecties van de bovenste luchtwegen en patiënten met S.aureus-infecties verspreiden hogere aantallen S.aureus dan gezonde dragers. In ziekenhuizen en verpleeghuizen is de kans op besmetting en verspreiding door contact met dragers en patiënten hoger dan daarbuiten. Mensen die in ziekenhuizen of verpleeghuizen werken, verpleegkundigen en artsen, zijn dan ook vaker drager van S.aureus dan de algemene bevolking.

\subsubsection{Infectie door S.aureus}

\section{Pathogenese}

Neusdragerschap van S.aureus is een belangrijke risicofactor voor het krijgen van een infectie. S.aureus is niet invasief, maar als de huid of slijmvliezen worden beschadigd kan S.aureus het onderliggende weefsel, de lymfbaan en de bloedbaan bereiken. Of dan een infectie ontstaat is afhankelijk van het aantal S.aureus dat aanwezig is, het weefsel waarin ze terechtkomen, de snelheid waarmee een ontstekingsreactie op gang komt en de algemene afweer van de persoon in kwestie. Als echter een infectie door S.aureus ontstaat in weefsel of een orgaan, wordt een abces

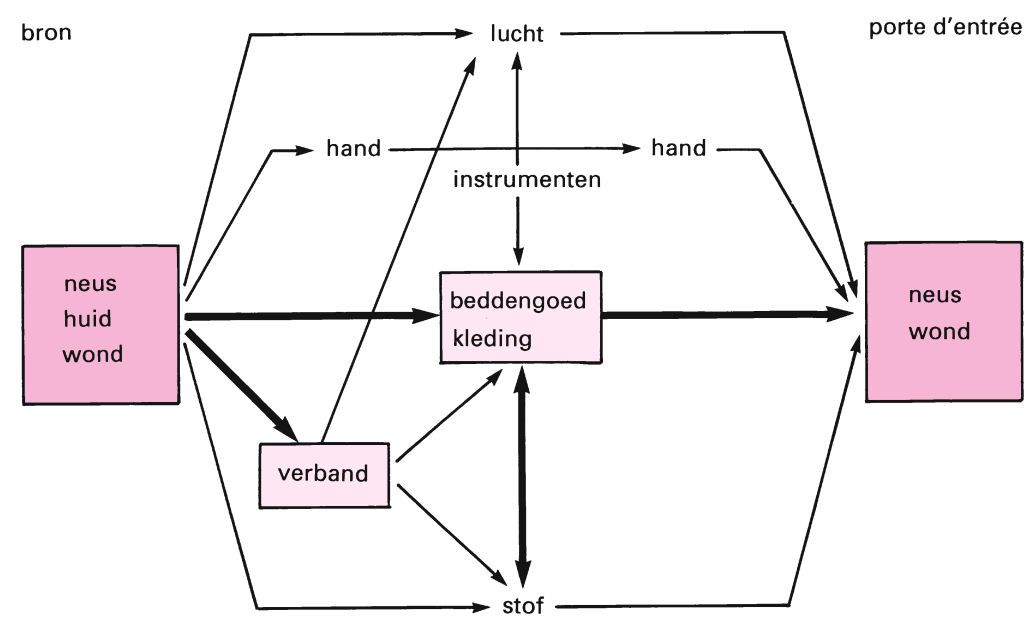

Figuur 12.7 Schematische weergave van de besmettingswegen van S.aureus. 
gevormd: een door fibrine afgekapselde holte gevuld met pus (etter) waarin dode en levende $S$. $a u$ reus en dode of necrotische weefselcellen en leukocyten. Een S.aureus-abces in de huid is een steenpuist (furunkel). Multipele S.aureus-abcessen dicht bij elkaar worden karbunkels genoemd. De vorming van een abces door S.aureus is complex en het resultaat van bacteriële eigenschappen en gastheercelfactoren. Hierbij spelen het peptidoglycaan en teichoïnezuur in de S.aureuscelwand een belangrijke rol door activatie van de alternatieve route van het complement en inductie van TNF en IL-1 (fig. 12.8). De acute ontstekingsreactie wordt gekenmerkt door een influx van fagocyterende granulocyten waartegen S.aureus zich teweerstelt. In de celwand van de bacterie komt een eiwit voor, proteïne $\mathrm{A}$, dat aspecifiek de Fc-gedeelten van immunoglobuline $G$ bindt. Daardoor wordt de opsonische functie van de immunoglobulinen uitgeschakeld, en kan S.au- reus aan de fagocyterende leukocyten ontsnappen. Dit is echter niet de enige verdedigingsstrategie van S.aureus tegen leukocyten. S.aureus produceert en scheidt ook exotoxinen en -enzymen uit, waarmee de functie van de neutrofiele granulocyten wordt beperkt of ontregeld of waardoor deze cellen worden beschadigd (zie fig. 12.8).

Het ontstoken gebied wordt afgekapseld door fibrinevorming, waarbinnen weefselcellen lyseren door uit gedode neutrofiele granulocyten vrijkomende proteasen. Dat is het begin van de voor een S.aureus-infectie kenmerkende abcesvorming in inwendige organen en weefsels. In de woorden van Louis Pasteur: een S.aureus-osteomyelitis is een steenpuist in het bot. Door het vermogen zich snel te verspreiden in het weefsel kan S.aureus ook in de bloedbaan terechtkomen. Dan is er sprake van een secundaire S.aureus-bacteriëmie, die niet zelden gepaard gaat met de klinische verschijnselen van ernstige sepsis (zie boven).

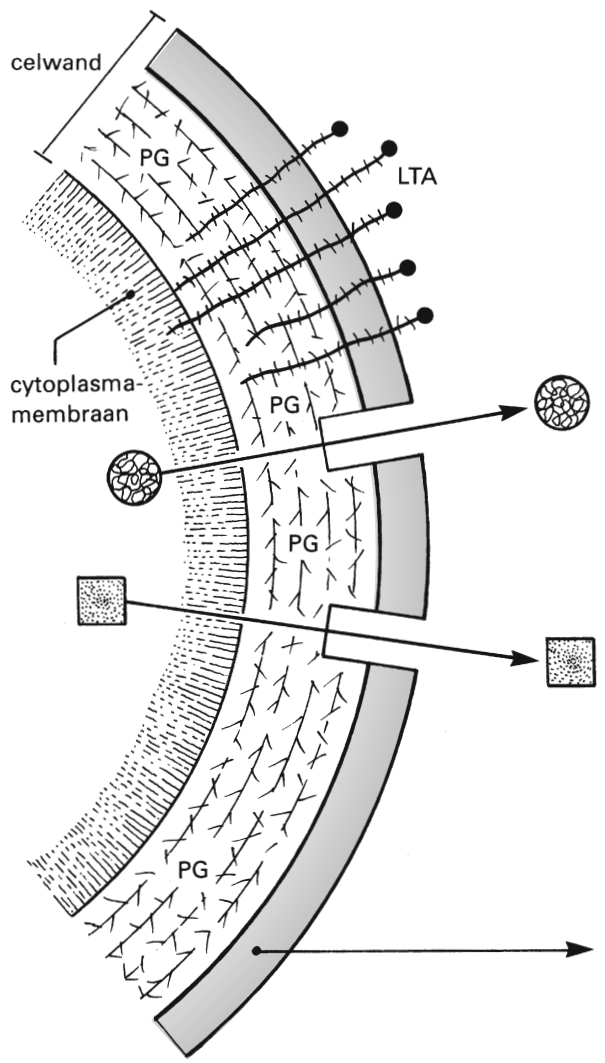

celwand

peptidoglycaanmatrix (PG): inductie TNF en IL-1 met covalent gebonden complementactivatie

- (lipo)teichoïnezuur (LTA): complementactivatie - proteïne A: bindt aan Fc-deel van antistoffen $\rightarrow$ remt opsonisatie

- clumping factor: adsorbeert fibrinogeen $\rightarrow$ fibrineafkapseling

- adhesie-eiwitten voor: collageen, fibronectine, elastine

exotoxinen
- leukocidine: lyseert leukocyten
- hemolysinen: beschadigen celwand van cellen
- enterotoxinen: beschadigen enterocyten, superantigeen
- TSST-1: superantigeen, inductie toxische shock
- epidermolytisch: blaarvorming van de huid (exfoliatine)

exo-enzymen

- coagulase: fibrinevorming $\rightarrow$ afkapseling

- hyaluronidase: splitst hyaluronzuur $\rightarrow$ verspreiding

- katalase: beschermt tegen $\mathrm{H}_{2} \mathrm{O}_{2}$

- nucleasen: afbraak DNA/RNA $\rightarrow$ verspreiding

- lipasen: lipolyse

- $\beta$-lactamase: afbraak $\beta$-lactam-antibiotica $\rightarrow$ resistentie

\section{(micro)kapsel van polysachariden}

- belemmering van fagocytose

Figuur 12.8 Virulentiefactoren van S.aureus. Zowel onderdelen van de celwand als door S.aureus uitgescheiden exotoxinen en enzymen dragen bij tot het ziekmakend vermogen van deze soort. 


\section{Aandoeningen door exotoxinevormende S.aureus}

Behalve de pusvormende gelokaliseerde infecties zijn er drie gegeneraliseerde aandoeningen die het gevolg zijn van door S.aureus gevormde exotoxinen. Elke aandoening ontstaat door een specifiek toxine. S.aureus die exfoliatine vormt, veroorzaakt huidafwijkingen: blaren of bullae gevuld met vocht (impetigo bullosa of pemphigus neonatorum) of het loslaten van de opperhuid (dermatitis exfoliativa neonatorum of 'staphylococcal scalded skin syndrome'). De huidafwijkingen ontstaan doordat het exfoliatine via een huid- of slijmvlieslaesie in de bloedbaan terechtkomt, zich hematogeen verspreidt en zich aan specifieke receptoren in de opperhuid kan binden. Hierdoor worden de intercellulaire verbindingen (desmosomen) in de epidermidis verbroken. Bij lichte aanraking laat de huid van de patiënt los. De aanduiding neonatorum wijst er al op dat deze aandoening vooral bij jonge kinderen voorkomt.

Een tweede door S.aureus-toxine veroorzaakte aandoening is het toxische-shocksyndroom (TSS). Dit is een acuut ziektebeeld met alle verschijnselen van ernstige sepsis, waarbij de bloedkweken meestal negatief zijn. Ongeveer $10-20 \%$ van de S.aureus-stammen vormt het TSS-toxine (TSST). Patiënten met TSS hebben meestal een gelokaliseerde S.aureus-infectie, bijvoorbeeld een huidinfectie of (postoperatieve) wondinfectie. De ziekte kreeg als 'de tamponziekte' grote bekendheid in het begin van de jaren tachtig toen vrouwen in de Verenigde Staten nieuwe superabsorberende vaginale tampons gingen gebruiken en TSS kregen. Door groei van S.aureus in de tampons werd veel TSST uitgescheiden, dat vervolgens na absorptie in de bloedbaan terechtkwam. Het TSST behoort tot de familie van de superantigenen (zie een leerboek immunologie). Ook enterotoxinen van S.aureus (zie verder) en de pyrogene exotoxinen van S.pyogenes behoren daartoe. De ziekteverschijnselen, die met name door interleukinen worden veroorzaakt, ontstaan binnen 12-48 uur, met het gevoel van een griepje. De patiënt braakt en krijgt diarree met hoge koorts $\left(>38,7^{\circ} \mathrm{C}\right)$, een lage systolische bloeddruk (hypotensie), hoofdpijn, spierpijn en buikpijn. Op de huid en slijmvliezen (ogen, mond, vagina) ont- staat een erytheem (een rode verkleuring), soms met petechiën en ulcera. De functies van hart, nier, lever en het beenmerg zijn sterk gestoord. Een week na het begin van de ziekte begint de huid te vervellen (desquamatie), ook op voetzolen en handpalmen. Eén à twee maanden later vallen nagels af en haren uit. TSS komt voor in een frequentie van 2-5 gevallen per miljoen, en is een ernstige ziekte waarvan de letaliteit $5-10 \%$ bedraagt.

De derde aandoening ontstaat door S.aureus, die enterotoxinen uitscheiden: de S.aureus-voedselvergiftiging. Ongeveer de helft van de S.aureusstammen vormt enterotoxine. Indien voedsel wordt besmet met enterotoxinevormende S.aureus (vaak door dragers) en niet koel wordt bewaard, gaan de bacteriën groeien en hoopt zich enterotoxine in het voedsel op. De consument van dit voedsel wordt binnen een paar uur misselijk, gaat hevig braken met buikkrampen en krijgt daarna vaak diarree. De klachten duren meestal niet langer dan een dag. Het koken van voedsel dat S.aureus-enterotoxine bevat, vrijwaart de consument niet van een voedselvergiftiging door S.aureus-enterotoxine omdat S.aureus-enterotoxinen hittestabiel zijn.

\section{Diagnose}

Voor de diagnose van S.aureus-infecties wordt materiaal uit een abces geaspireerd. De pus wordt in het laboratorium met behulp van een Gram-kleuring onderzocht. In het preparaat zijn veel leukocyten en Gram-positieve kokken in groepjes te zien (fig. 12.9). Van op een bloedagarplaat gegroeide kolonies wordt een coagulasetest gedaan om S.aureus te onderscheiden van S.epidermidis. Bij patiënten die verdacht worden van een S.aureus-infectie, worden altijd bloedkweken afgenomen. S.aureus-infecties als artritis, osteomyelitis en endocarditis gaan meestal gepaard met een bacteriëmie, terwijl materiaal voor kweek van dergelijke infectiehaarden moeilijk te verkrijgen is.

De diagnostiek van aandoeningen die door toxinevormende S.aureus worden veroorzaakt, berust vooral op het klinisch beeld. De specifieke toxinen kunnen worden aangetoond bij de patiënt of, in geval van een S.aureus-voedselvergiftiging, bij uit het voedsel gekweekte S.aureus. Ten 


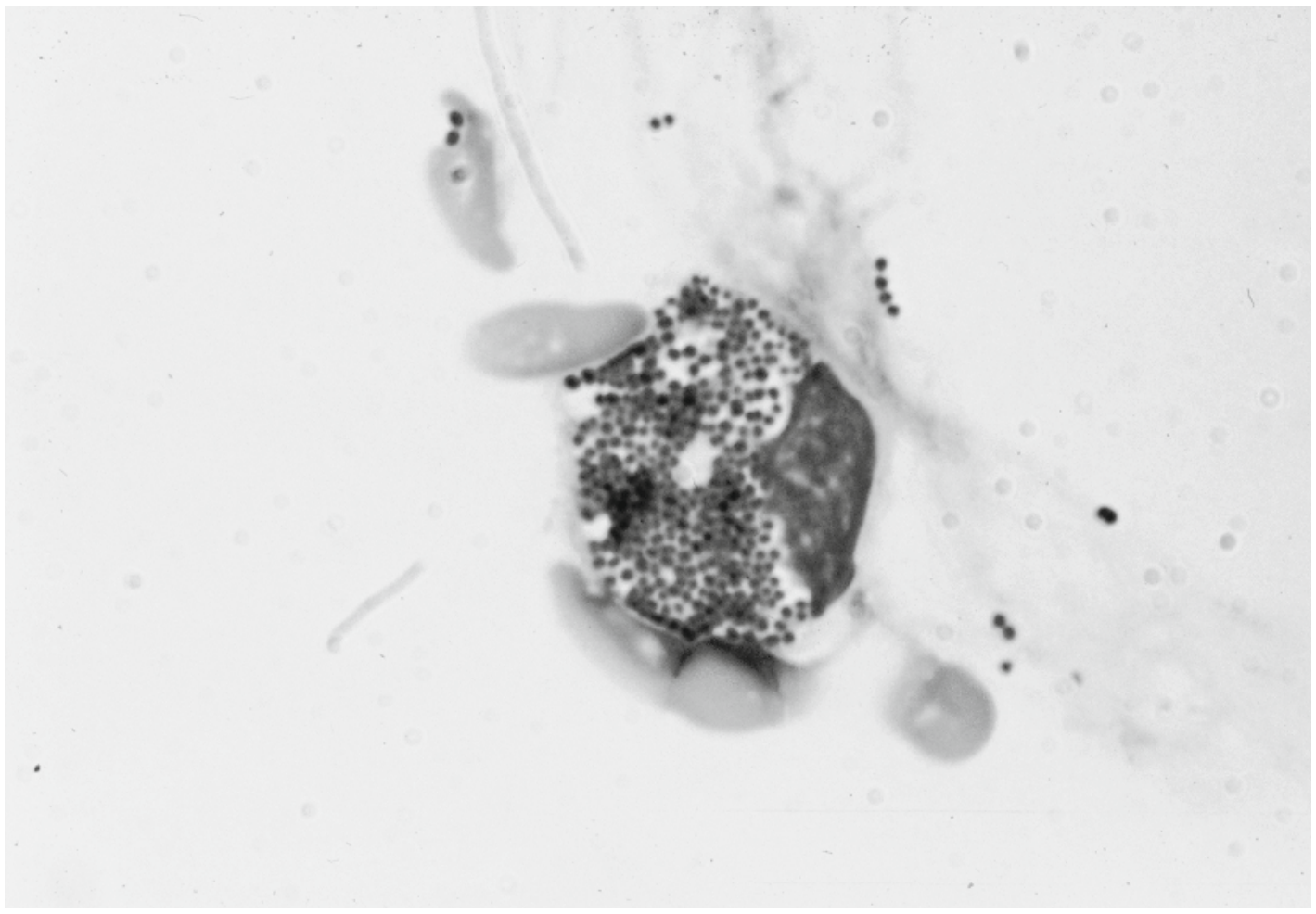

Figuur 12.9 S.aureus: Gram-positieve bacteriën die in een druiventros liggen, hier in associatie met granulocyten in een preparaat van pus.

slotte heeft ook het aantonen van (een significante titerstijging van) antistoffen tegen bepaalde exotoxinen (TSST en alfatoxine [een hemolysine]) diagnostische betekenis, met name bij acute infecties en voor het bepalen van de recidiefkans (bij TSS).

\section{Behandeling}

Oppervlakkige huidinfecties (impetigo) genezen vaak spontaan. Bij de behandeling zijn hygiënische maatregelen zoals het wassen met een desinfecterende zeep en het kortknippen van nagels belangrijk. S.aureus-abcessen worden geïncideerd. Deze patiënten krijgen evenals patiënten met acute S.aureus-infecties (bacteriëmie, sepsis, endocarditis, pneumonie) antibiotica. Toen penicilline ruim vijftig jaar geleden beschikbaar kwam, waren alle S.aureus-stammen penicillinegevoelig. $\mathrm{Nu}$ is $90-95 \%$ van de S.aureus-stammen penicillineresistent, doordat zij een penicilline-afbrekend enzym (bètalactamase) produceren. Voor de behandeling van S.aureus-infecties wordt daarom gebruikgemaakt van bètalactamase-ongevoelige penicillinen zoals flucloxacilline. Ook tegen deze antibiotica is de afgelopen 25 jaar echter resistentie ontstaan. De meeste meticillineresistente S.aureus-stammen (MRSA-stammen) zijn ook ongevoelig voor diverse andere antibiotica. In de ons omringende landen, in Japan en in de Verenigde Staten is $20-60 \%$ van de S.aureus-stammen meticillineresistent. In Nederland is door het toegepaste antibioticabeleid en door actieve opsporing van (de import van) MRSA-dragers het aantal patiënten met MRSA tot $\mathrm{nu}$ toe beperkt gebleven. Infecties ten gevolge van MRSA worden behandeld met glycopeptideantibiotica zoals vancomycine.

\section{Preventie}

Het neusdragerschap van S.aureus kan als belangrijke risicofactor tijdelijk worden opgeheven door behandeling van dragers met muporicineneuszalf; hierdoor reduceert men het aantal S.au- 
reus-infecties na grote operaties, en ook bij patiënten die chronisch gedialyseerd moeten worden. Ook patiënten met recidiverende furunculose hebben baat bij een behandeling met mupirocine. Er worden ook veel preventieve maatregelen genomen om besmetting te voorkomen of teniet te doen: aseptische maatregelen bij de wondverzorging in en buiten de operatiekamer, aanbrengen van een desinfecterende zalf of oplossing op de navelstomp bij pasgeborenen, en strikte isolatie van een MRSA-positieve patiënt in het ziekenhuis. Ten slotte heeft toepassing van gerichte antimicrobiële profylaxe bij verschillende operaties het aantal patiënten met postoperatieve wondinfecties door S.aureus drastisch doen dalen.

\subsubsection{Andere stafylokokken: CONS}

De infecties door CONS ontstaan, met uitzondering van urineweginfecties, door S.saprophyticus, meestal in het ziekenhuis. De urineweginfecties door S.saprophyticus worden bijna uitsluitend gevonden bij jonge vrouwen (16-35 jaar). De klinische verschijnselen zijn dezelfde als bij urineweginfecties door andere bacteriën (zie hfdst. 4). De infecties door CONS die geassocieerd zijn met intravasale katheters en geïmplanteerde kunststoffen, worden in hoofdstuk 14 besproken. Doorgaans zijn CoNs-soorten minder virulent dan S.aureus doordat zij trager groeien en weinig of geen exotoxinen produceren; wel hechten cons goed aan allerlei kunststoffen die in de geneeskunst worden toegepast, zoals prothesen, implantaten en katheters. Infecties met CONS rond dergelijke biomaterialen hebben vaak een chronisch, indolent karakter, en hebben deze bacteriën de bijnaam 'plastic pathogens' opgeleverd.

Voor de therapie van cons-infecties is het aantal antibiotica beperkt. De meeste CONS zijn resistent tegen penicilline en andere groepen antibiotica. Hoewel vancomycineresistente CONS voorkomen, wordt dit antibioticum als eerste keus gebruikt voor de behandeling van CONS-infecties. Maatregelen voor de preventie van CONS-infecties worden in hoofdstuk 14 besproken.

\subsection{Andere infecties van het hart: myocarditis en pericarditis}

Naast endocarditis komen ook andere infecties van het hart voor: myocarditis en pericarditis. Beide aandoeningen kunnen behalve door microorganismen ook door verschillende niet-infectieuze oorzaken ontstaan. Myocarditis (infecties van de hartspier of het myocard) en pericarditis (infecties van het hartzakje of pericard) kunnen worden veroorzaakt door vrijwel alle micro-organismen (virussen, bacteriën, gisten, schimmels, protozoën) en parasieten die het hart via de bloedbaan bereiken. Door de infectie of bacteriële toxinen neemt de contractiliteit van de hartspier af en ontstaan de klinische verschijnselen van hartinsufficiëntie (decompensatio cordis) en hartritmestoornissen. Voor de diagnose myocarditis is een uitgebreid onderzoek van de hartfuncties en microbiologisch onderzoek van onder meer hartspierbiopten en bloed nodig.

Virale pericarditis komt in de westerse landen veel vaker voor dan bacteriële pericarditis, vooral door virussen uit Cocksackie groep B. Virale pericarditis gaat bijna altijd gepaard met pijn in de hartstreek. De patiënt met bacteriële pericarditis is meestal acuut ziek geworden, met koorts en dyspneu of kortademigheid. Door de infectie in het pericard neemt de hoeveelheid pericardvocht toe. Door afzetting van fibrine op de pericardbladen ontstaan bij de hartbeweging wrijfgeluiden die bij auscultatie gehoord kunnen worden. Voor de diagnose van pericarditis is het ECG van groot belang. Een toename van het pericardvocht van 15 $\mathrm{ml}$ of meer verstoort het normale hartgeleidingspatroon. Voor de diagnose wordt pericardvocht geaspireerd voor microbiologisch onderzoek. Bij patiënten verdacht voor bacteriële pericarditis worden ook altijd bloedkweken afgenomen.

\subsection{Secundaire bloedbaaninfecties}

Vanuit lokale infecties kunnen micro-organismen de bloedbaan bereiken. Dan is sprake van een secundaire bacteriëmie. Als daarbij klinische verschijnselen van sepsis of ernstige sepsis ontstaan, is sprake van een secundaire bloedbaaninfectie. 
Een bacteriëmie kan ook ontstaan zonder dat een geïnfecteerd focus aantoonbaar is. Dan wordt gesproken van een primaire bacteriëmie en van primaire bloedbaaninfecties indien manifestaties van het inflammatoire-responssyndroom (SIRS) ontstaan. De afgelopen 30-40 jaar is het aantal patiënten met bloedbaaninfecties toegenomen. De stijging betreft vooral het aantal gevallen dat tijdens opname in het ziekenhuis ontstaat in het kader van het medisch en verpleegkundig handelen. De frequentie van bloedbaaninfecties in Nederland bedraagt in de afgelopen jaren 8-12 gevallen per 1000 ziekenhuisopnamen. In het ziekenhuis ontstaat ongeveer $60 \%$ van alle gevallen van bloedbaaninfectie (nosocomiale bacteriëmie en sepsis). De sepsis die in het ziekenhuis ontstaat, wordt in hoofdstuk 14 besproken.

Gemiddeld overlijdt 20-30\% van de patiënten met een bloedbaaninfectie; van de patiënten met een septische shock sterft $50 \%$ en van de patiënten met multipel orgaanfalen (MOF) $80 \%$.

\section{Pathogenese}

Bij sommige aandoeningen ontstaat bij een geringe bacteriëmie al snel sepsis. Voorbeelden hiervan zijn patiënten met een granulocytopenie en patiënten zonder milt (asplenie).

De septische verschijnselen ontstaan doordat bacteriën of bestanddelen van bacteriën een systemisch SIRS in de bloedbaan veroorzaken (tabel 12.9). Voor E.coli, een Gram-negatieve staafvormige bacterie, is endotoxine, een celwandbestanddeel, de belangrijkste ontstekingscomponent. Voor andere bacteriën ontstaat de ontsteking door andere celwandbestanddelen (peptidoglycaan, lipoteichoïnezuur). Ook diverse toxinen - denk bijvoorbeeld aan het toxischeshocksyndroom door S.aureus - veroorzaken een heftige ontstekingsreactie in de bloedbaan. De wijze waarop dergelijke bacteriële componenten de ontstekingsreactie (SIRS) induceren, is elders besproken (zie hfdst. 1).

\section{Epidemiologie}

Bij patiënten met een bacteriëmie of sepsis moet altijd gezocht worden naar een focus dat de porte d'entrée vormt.

Buiten het ziekenhuis komen secundaire bloedbaaninfecties veel meer voor dan primaire: in $80 \%$ van de gevallen is een geïnfecteerd focus aanwezig. Vaak is dat een infectie in de urinewegen (fig. 12.10A). Bij patiënten met pneumokokkenpneumonie komt S.pneumoniae vanuit de geinfecteerde longen in de bloedbaan terecht. In het ziekenhuis komt een primaire bloedbaaninfectie vaker voor dan een secundaire (fig. 12.10B). Dit komt vooral door het grote aantal patiënten met intravasale katheters dat een lijnsepsis krijgt, meestal door CONS, die vanaf de huid via de insteekopening van de katheter direct in de bloed-

Tabel 12.9 Bacteriële componenten waardoor sepsis ontstaat.

\begin{tabular}{|c|c|c|}
\hline bacteriële component & \multicolumn{2}{|l|}{ bacteriën } \\
\hline endotoxine (lipopolysacharide) & \multicolumn{2}{|l|}{ Gram-negatieve bacteriën } \\
\hline peptidoglycaan & \multicolumn{2}{|l|}{ Gram-positieve bacteriën } \\
\hline & \multicolumn{2}{|l|}{ (Gram-negatieve bacteriën) } \\
\hline lipoteichoïnezuur & \multicolumn{2}{|l|}{ Gram-positieve bacteriën } \\
\hline \multirow{3}{*}{$\begin{array}{l}\text { porievormend toxine (maakt } \mathrm{g} \\
\text { in cytoplasmamembraan) }\end{array}$} & Staphylococcus aureus & $\alpha$-hemolysine \\
\hline & Streptococcus pyogenes & streptolysine \\
\hline & Escherichia coli & hemolysine \\
\hline \multirow[t]{2}{*}{ superantigenen } & Staphylococcus aureus & TSST- 1 enterotoxine A $\mathrm{t} / \mathrm{m} \mathrm{F}$ \\
\hline & Streptococcus pyogenes & pyrogeen exotoxine \\
\hline \multirow[t]{2}{*}{ enzymen } & Streptococcus pyogenes & IL-1B-convertase \\
\hline & Clostridium perfringens & fosfolipase \\
\hline
\end{tabular}




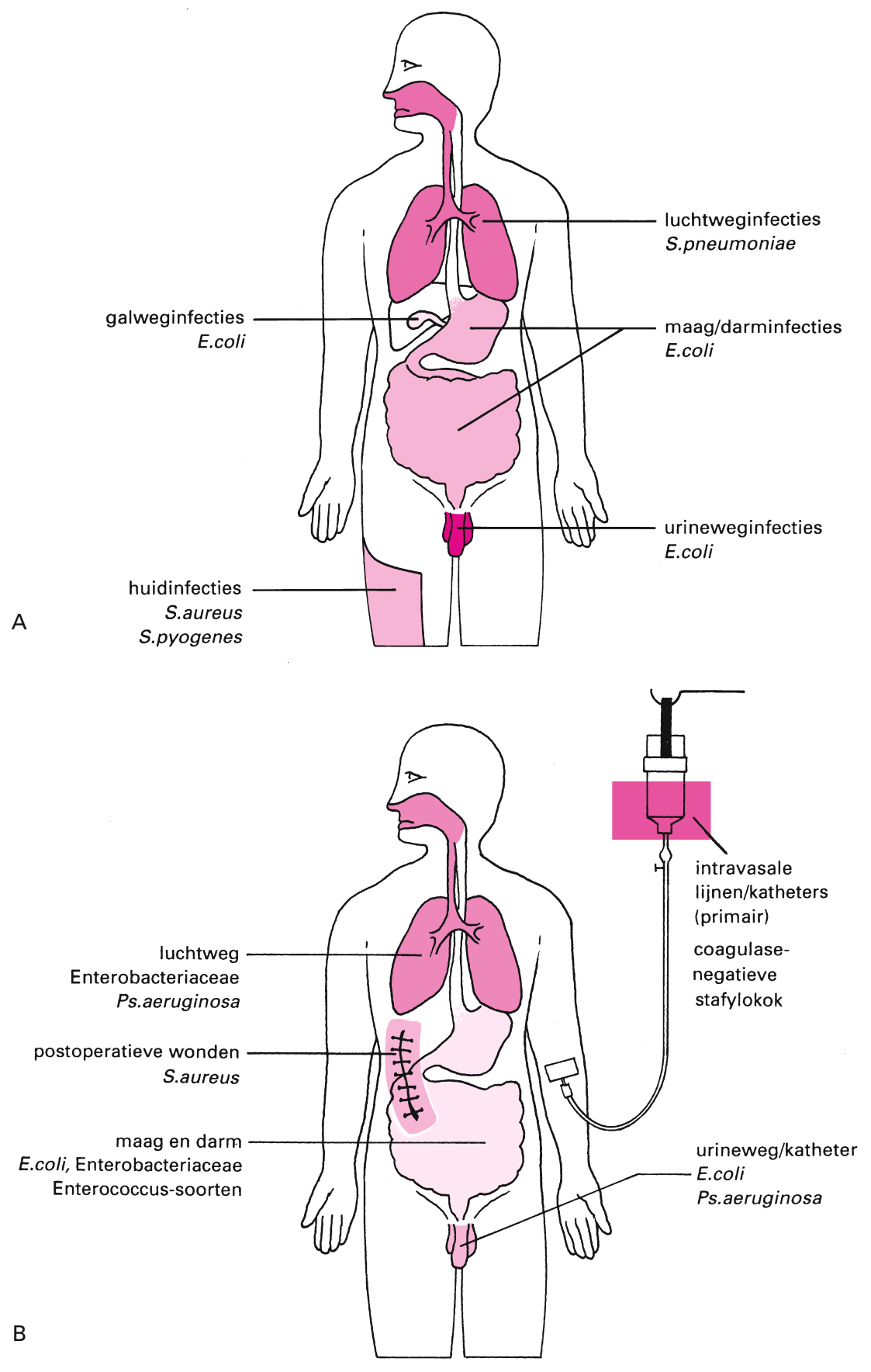

Figuur 12.10 Portes d'entrée voor bacteriëmie en sepsis: $A$ bij patiënten buiten het ziekenhuis, B bij patiënten in het ziekenhuis. De intensiteit van de kleur van de aangeduide portes d'entrée correleert met het relatieve belang bij het ontstaan van bacteriëmie en sepsis.

baan terechtkomen. Ook verschilt het spectrum van de verwekkers die bloedbaaninfecties buiten en in het ziekenhuis veroorzaken. CONS en Candida-infecties ontstaan vrijwel uitsluitend bij patiënten in het ziekenhuis, terwijl infecties door pneumokokken en $\beta$-hemolytische streptokokken bijna nooit in het ziekenhuis ontstaan. E.coliinfecties ontstaan vaker buiten dan in het ziekenhuis, terwijl Enterococcus, Enterobacter en Klebsiella-soorten evenals P.aeruginosa vaker infec- 
Tabel 12.10 Verwekkers van een secundaire bloedbaaninfectie en hun potentiële portes d'entrée.

micro-organisme

Staphylococcus aureus

Streptococcus pneumoniae

$\beta$-hemolytische streptokokken

Escherichia coli, Enterococcus

andere Enterobacteriaceae

Pseudomonas aeruginosa

Bacteroides, anaëroben waarschijnlijke infectiehaard/porte d'entrée

huidinfectie: furunkel, paronychia, geïnfecteerde wond

pneumonie, otitis media, sinusitis

huidinfectie, geïnfecteerde wond, urogenitale infectie

urineweginfectie, galweginfectie, darminfectie

galweginfectie, darminfectie

urineweginfectie

mond-keelholte-infectie, darminfectie, urogenitale infectie ties veroorzaken bij patiënten in het ziekenhuis dan daarbuiten. Er bestaat derhalve een duidelijke relatie tussen het spectrum van de verwekkers van bloedbaaninfecties en het geïnfecteerde focus van waaruit de bacteriën of gisten in de bloedbaan zijn terechtgekomen. Urineweginfecties zijn vaak de bron voor E.coli- en Enterococcus-infecties. Bloedbaaninfecties door E.coli kunnen eveneens ontstaan ten gevolge van galweg- en darminfecties. Huidinfecties of geïnfecteerde wonden zijn dikwijls de bron voor sepsis door S.aureus en $\beta$-hemolytische streptokokken

\section{Klinische verschijnselen}

Patiënten met een secundaire bloedbaaninfectie hebben meestal ook klachten en verschijnselen van de lokale infectiehaard. Patiënten met een S.pneumoniae-infectie hebben bijvoorbeeld klachten van bovenste-luchtweginfecties (sinusitis, otitis) of van een pneumonie.

Hoewel de verschijnselen van bloedbaaninfecties divers zijn, is het klinisch onderzoek van groot belang. Elke patiënt met een plotseling optredende koorts, koude rillingen, een verhoogde ademhalingsfrequentie (tachypneu) en hartfrequentie (tachycardie), hypotensie en een afname van de diurese (verminderd plassen) kan een (secundaire) bloedbaaninfectie hebben. Bij inspectie en lichamelijk onderzoek wordt gezocht naar het voorkomen van geïnfecteerde foci die de oorzaak kunnen zijn van de sepsis. De slagpijn in de nierloge duidt op een pyelonefritis. Soms zijn er ook afwijkingen die min of meer specifiek zijn voor de bacterie die de oorzaak is van de sepsis. Bij patiënten met een meningokokkensepsis zijn er niet zelden petechiae in huid of slijmvliezen, ter- wijl bij het toxische-shocksyndroom door S.aureus of S.pyogenes (groep A) in de huid, ogen en slijmvliezen een erytheem aanwezig is.

\section{Diagnose}

Isolatie en identificatie van de verwekkers van de sepsis is noodzakelijk om de diagnose zeker te stellen en om de gevoeligheid voor antibiotica te kunnen vaststellen. Bloedkweken worden altijd voor de antimicrobiële behandeling afgenomen. Een bloedkweek kan al na 6-8 uur groei vertonen, maar het kan ook 24-48 uur duren voordat de kweek positief wordt. Dit is afhankelijk van de bacteriesoort die de sepsis veroorzaakt en het aantal bacteriën in de bloedbaan (meestal slechts $1-30 / \mathrm{ml}$ ). Als een potentiële infectiehaard in beeld wordt gebracht, wordt ook daarvan, indien mogelijk, materiaal microbiologisch onderzocht.

\section{Therapie}

Patiënten met een secundaire bloedbaaninfectie zijn acuut en ernstig ziek en worden doorgaans in het ziekenhuis opgenomen. Omdat bij opname niet bekend is wat de mogelijke verwekker(s) van de sepsis is (zijn), wordt begonnen met een combinatie van antibiotica waarvoor een groot aantal bacteriesoorten gevoelig is. Bij de keuze van de antibiotica wordt rekening gehouden met de vermoedelijke porte d'entrée en de meest waarschijnlijke verwekkers (empirische behandeling). Van belang is ook dat de lokale infectie of bron adequaat wordt behandeld door bijvoorbeeld drainage van een abces en/of verwijdering van geïnfecteerde katheters.

Naast de antimicrobiële therapie krijgen patiënten met een bloedbaaninfectie een behandeling 
voor de stoornissen van de bloedcirculatie en van de functie van de diverse organen. Hiervoor worden infusen met vocht gegeven, zo nodig bloeddrukverhogende medicijnen en wordt extra zuurstof toegediend. Het doel van deze behandeling is een adequate weefselperfusie en herstel van de oxygenatie van de weefsels. Ook de verhoogde stollingsneiging wordt bestreden.

\section{Preventie}

Buiten het ziekenhuis is preventie van infecties van waaruit micro-organismen in de bloedbaan terechtkomen nauwelijks mogelijk. De ontwikkeling van vaccins tegen de meest voorkomende verwekkers van sepsis is nog nauwelijks op gang gekomen; wel zijn er vaccins beschikbaar tegen de meest voorkomende typen pneumokokken en worden bepaalde risicogroepen daarmee ingeënt. Introductie van een vaccin tegen H.influenzae type $B$ in het Rijksvaccinatieprogramma halverwege de jaren negentig heeft de incidentie van invasie-infecties met deze bacteriesoort onder jonge kinderen drastisch verlaagd. Ook het op grote schaal toepassen van het griepvaccin heeft een potentieel gunstig effect op het voorkomen van secundaire bacteriële bloedbaaninfecties vanuit de luchtwegen. In het ziekenhuis bestaat de preventie van sepsis uit het juist en zorgvuldig toepassen van de richtlijnen voor de preventie van ziekenhuisinfecties en de richtlijnen van antimicrobiële profylaxe.

\section{Kernpunten}

- Intravasale infecties zijn infecties van het bloed, de bloedvaten en het hart.

- Sepsis is een klinische manifestatie van een gegeneraliseerd ontstekingsproces, het systemische inflammatoire-responssyndroom (SIRS).

- Endocarditis is een primaire intravasale infectie op of in het hart (natieve endocarditis) of kunstkleppen (prothetische endocarditis).

- Endocarditis wordt in de meeste gevallen veroorzaakt door bacteriën.

- Subacute endocarditis wordt teweeggebracht door minder virulente bacteriën, vaak viridansstreptokokken.

- Acute endocarditis wordt teweeggebracht door virulente, invasieve bacteriën, vaak S.aureus.

- De klinische verschijnselen van subacute endocarditis zijn het gevolg van een continue bacteriëmie door groei van bacteriën op vegetaties in het hart.

- De klinische verschijnselen van acute endocarditis ontstaan in aansluiting op een bacteriëmie en zijn gekenmerkt door sepsis, klepbeschadiging en metastatische infecties.

- De diagnostiek berust op een combinatie van bevindingen van bloedkweken, klinisch en echocardiografisch onderzoek.

- Een therapie met antibiotica van enkele weken is nodig.

- Secundaire bloedbaaninfecties worden veroorzaakt door micro-organismen die vanuit lokale infecties de bloedbaan bereiken.

- Voor de diagnose van secundaire bloedbaaninfecties worden bloedkweken afgenomen.

- De antimicrobiële therapie wordt ondersteund met een behandeling voor de stoornissen van de circulatie en van de functies van de diverse organen.

\section{Literatuur}

Kaye D. Infective endocarditis. New York: Raven Press, 1992.

Wenzel RP, Pinsky MR, Ulevitch RJ, Young L. Current understanding of sepsis. Clin Infect Dis 1996; 22: 407-13. 